NBER WORKING PAPER SERIES

\title{
CHALLENGES IN BANKING THE RURAL POOR: EVIDENCE FROM KENYA'S WESTERN PROVINCE
}

\author{
Pascaline Dupas \\ Sarah Green \\ Anthony Keats \\ Jonathan Robinson \\ Working Paper 17851 \\ http://www.nber.org/papers/w17851 \\ NATIONAL BUREAU OF ECONOMIC RESEARCH \\ 1050 Massachusetts Avenue \\ Cambridge, MA 02138 \\ February 2012
}

We thank Kathy Nolan and Kim Siegal for excellent research assistance and IPA Kenya for managing the field work. We thank Cynthia Kinnan, William Lyakurwa, and conference participants at Strathmore University and the 5th NBER Africa conference for helpful comments and suggestions. This study was funded through grants from the International Growth Center, the NBER Africa project, and the International Initiative for Impact Evaluation (3ie). All errors are our own. The views expressed herein are those of the authors and do not necessarily reflect the views of the National Bureau of Economic Research.

NBER working papers are circulated for discussion and comment purposes. They have not been peerreviewed or been subject to the review by the NBER Board of Directors that accompanies official NBER publications.

(C) 2012 by Pascaline Dupas, Sarah Green, Anthony Keats, and Jonathan Robinson. All rights reserved. Short sections of text, not to exceed two paragraphs, may be quoted without explicit permission provided that full credit, including $\odot$ notice, is given to the source. 
Challenges in Banking the Rural Poor: Evidence from Kenya's Western Province

Pascaline Dupas, Sarah Green, Anthony Keats, and Jonathan Robinson

NBER Working Paper No. 17851

February 2012

JEL No. D14,G21,O16

\begin{abstract}
$\underline{\text { ABSTRACT }}$
Most people in rural Africa do not have bank accounts. In this paper, we combine experimental and survey evidence from Western Kenya to document some of the supply and demand factors behind such low levels of financial inclusion. Our experiment had two parts. In the first part, we waived the fixed cost of opening a basic savings account at a local bank for a random subset of individuals who were initially unbanked. While $63 \%$ of people opened an account, only $18 \%$ actively used it. Survey evidence suggests that the main reasons people did not begin saving in their bank accounts are that: (1) they do not trust the bank, (2) service is unreliable, and (3) withdrawal fees are prohibitively expensive. In the second part of the experiment, we provided information on local credit options and lowered the eligibility requirements for an initial small loan. Within the following 6 months, only 3\% of people initiated the loan application process. Survey evidence suggests that people do not borrow because they do not want to risk losing their collateral. These results suggest that, while simply expanding access to banking services (for instance by lowering account opening fees) will benefit a minority, broader success may be unobtainable unless the quality of services is simultaneously improved. There are also challenges on the demand side, however. More work needs to be done to understand what savings and credit products are best suited for the majority of rural households.
\end{abstract}

Pascaline Dupas

Department of Economics

Stanford University

579 Serra Mall

Stanford, CA 94305-6072

and NBER

pdupas@stanford.edu

Sarah Green

Innovations for Poverty Action

101 Whitney Ave

New Haven, CT 06510

sgreen@poverty-action.org

\author{
Anthony Keats \\ Department of Economics \\ University of California, Los Angeles \\ 8283 Bunche Hall \\ Los Angeles, CA 90095 \\ akeats@ucla.edu \\ Jonathan Robinson \\ Department of Economics \\ University of California, Santa Cruz \\ 457 Engineering 2 \\ Santa Cruz, CA 95064 \\ jmrtwo@ucsc.edu
}




\section{Introduction}

Access to basic banking services in Sub-Saharan Africa remains limited, and lags far behind even other parts of the developing world. Chaia et al. (2009) combine a number of data sources to estimate that only about $20 \%$ of households in Sub-Saharan Africa were banked in the early 2000s. ${ }^{1}$ While there has been some progress in recent years, Kendall et al. (2010) obtain similar results using more recent data. While developing countries have only $28 \%$ as many bank accounts per adult as do developed countries, the figure in Sub-Saharan Africa is far lower (only 16\%). Lack of access is particularly acute in rural areas: representative household survey data we collected between 2009 and 2011 suggest that only between 15 and 21 percent of households are banked in rural areas of Kenya, Malawi, and Uganda, respectively. ${ }^{2}$

Such limited access could potentially have important repercussions on people's lives. If lacking a formal bank account makes it more difficult for people to save, they will be unlikely to have enough saved up to cope with unexpected emergencies such as household illness. When such shocks occur, rather than withdraw money or take a loan from the bank, people might have to take much costlier actions. ${ }^{3}$ Lack of banking access might also make it difficult for people to save up large sums or obtain credit for lumpy purchases such as start-up costs for a business, agricultural inputs, or even preventative health products like anti-malarial bednets.

Given this, expanding access to even very basic savings and credit services could have large effects. The existing evidence on this issue is somewhat mixed, however. Recent studies suggest that expanding access to microloans alone has only modest effects on most outcomes (i.e. Banerjee et al 2010; Crépon et al 2011; Karlan and Zinman 2010). In contrast, studies of programs that increased access to both credit and savings services have found important welfare impacts (see Burgess and Pande, 2005 in India; and three studies in Mexico by Aportela, 1999, Bruhn and Love, 2009, and Ruiz, 2010). Expansion of saving services alone also appears to have the potential to be beneficial. In an earlier experimental study in Kenya, Dupas and Robinson (2009) provided small-scale entrepreneurs access to accounts in a local Village Bank, and found large effects on business investment and income among a subsample of the study population (market vendors, who are mostly female). In a similar experiment in Nepal, Prina (2011) also finds large impacts of expanding access to savings accounts for women.

From a policy standpoint, in addition to understanding the impact of financial inclusion, a critical question is how to achieve it. This is an area that has seen a lot of innovation in the last five years. These recent innovations ultimately amount to either reducing barriers to access to existing financial institutions (e.g., reducing fees); or bringing banking options geographically closer to people. 4 For example, a number of countries have adopted "correspondent" or "agent"

\footnotetext{
${ }^{1}$ Much of their financial access data is from Honohan (2008).

${ }^{2}$ At the country level, Chaia et al. (2009) find a weak relationship between urbanization and financial access.

${ }^{3}$ Examples of such costly actions include taking children out of school to work on the farm (see Ferreira and Schady 2009 for a recent review article), selling off assets such as business inventory (Dupas and Robinson 2009) or productive animals (Rosenzweig and Wolpin 1993), or engaging in income-generating activities which entail health risk (Robinson and Yeh 2011).

${ }^{4}$ Examples of the former type of innovations include the 2006 call made by the Reserve Bank of India to all
} 
banking in which people can deposit into and withdraw money from their bank account using a non-bank agent (for example, a retail store). ${ }^{5}$ A closely related option which has received a substantial amount of recent attention is "mobile money," in which people can transfer, deposit, and withdraw money using their cell phone (Jack and Suri, 2009). A third approach is a "bank on wheels" in which a vehicle visits a town at a regular interval for people to make transactions. ${ }^{6} \mathrm{~A}$ less glamorous approach would be to simply build more ATMs or bank branches (as Equity Bank has done in Kenya with great success - see Allen et al. 2011).

While much attention has recently been paid to these various strategies to expand access, comparatively little attention has been paid to the quality of financial services in very rural areas. If people are not banked because they do not trust banks or banking agents, because they find services to be unreliable, or because account maintenance or withdrawal fees are prohibitive, then expanding such flawed services is unlikely to be appealing. On the demand side, little attention has been paid to understanding reasons other than access for why people may choose to stay out of the formal banking system. This paper combines survey and experimental evidence from Western Kenya to show that addressing these supply and demand factors is crucial if financial services are to be expanded usefully to unbanked populations.

Our study takes place in an area spanning multiple villages surrounding three rural market centers in Western Kenya, and in which banking options remain very limited. In this part of Kenya, large bank branches are located only in major towns, and the villages in our study are far enough away from a town that the cost of traveling there for banking is prohibitive. Locally, there are only two options: a "Village Bank", owned by share-holding villagers and affiliated with a microfinance organization, and a partial-service branch (essentially a sales and information office with an ATM) for a major Commercial Bank. Both banks have substantial minimum balance requirements and withdrawal fees. The Village Bank also has an account opening fee. The Village Bank does not pay interest on deposits; effectively, neither does the Commercial Bank, at least for the poor (interest is only paid if the account balance exceeds $20,000 \mathrm{Ksh}$, or about $\$ 210$ ).

To examine financial access among this population, we conducted a census of 1,898 households in the study area between September and December 2009. Account ownership was quite low: only $20 \%$ of households had at least one member with a bank account. Knowledge of banking options was also limited, as only $60 \%$ of adults knew of the bank branches in the study area. Almost no one knew the fee schedule for account opening or maintenance. The 1,565 unbanked individuals formed the final experimental study sample.

To test whether opening costs (information acquisition, account opening fees, and administrative requirements) explained the low rates of account ownership, we randomly selected $55 \%$ of the 1,565

Commercial Banks to introduce free "no-frills" accounts (Thyagarajan and Venkatesan, 2008); or the 2010 pledge by the Bill and Melinda Gates foundation to contribute of $\$ 500$ million over 5 years towards increasing access to savings accounts in poor countries (Bill and Melinda Gates Foundation, 2010).

${ }^{5}$ See Kumar et al. (2006) for evidence on agent banking in Brazil. McKinsey and Company (2010) provide some background on correspondent banking in several other Latin American countries.

${ }^{6}$ Though such banking products exist in many countries, there are few academic studies of their impact. See Stuart et al. (2011) for evidence from Malawi and Nguyen Tien Hung (2004) for evidence from Vietnam. 
unbanked individuals to receive a free account at either of the two local banks. We paid the account opening fees and provided the minimum balance, and arranged for the banks to simplify the account opening procedure for our study participants. We did not waive withdrawal fees. The majority of people opened accounts when offered this opportunity: take-up was over $60 \%$. But actual account usage was much lower. Only $28 \%$ of those who opened an account (18\% of those randomly selected for a free account) made at least two deposits on their account in the 12 months after account opening. Many did not use the account at all.

Why didn't the other $80 \%$ of those selected to receive a free account actively use it? To shed light on this question, we administered qualitative surveys in which respondents could discuss their concerns with the various savings mechanisms available to them. A significant proportion listed risk of embezzlement, unreliable services, and transaction fees as concerns with formal banking. Many of these concerns are valid: the fees are indeed quite high in both the Village and Commercial Bank, and the services in one branch of the Village Bank were relatively poor during this time period. Furthermore, another branch of the Village Bank had a recent banking scandal in which withdrawals were frozen for some account holders for a long period. Not surprisingly, we find that trust concerns are more pronounced for the village with the branch with the recent scandal, and reliability concerns are worse for those near the branch with poor service. Interestingly, these concerns were reinforced by exposure to the bank: those who did use their account were more concerned with both the risk of fraud and the lack of reliability than those who did not use the account.

We use a similar combination of survey and experimental evidence to examine the demand for formal loans. The banks offer a variety of loans which range in interest between 1.25 and $1.5 \%$ per month (16\%-19.5\% APR), well below that of many microfinance banks in other parts of the world, ${ }^{7}$ and well below recent estimated returns to capital, including estimates from previous work in this part of Kenya. ${ }^{8}$ Yet, very few people take out loans. Of those in our experimental sample, only $6 \%$ had ever applied for a formal loan at baseline. As with savings options, knowledge of loan options appears extremely limited - very few people know what the conditions are for loans with either bank. Further, when asked, very few people reported wanting loans for agricultural inputs such as fertilizer, despite the high estimated returns to usage in Kenya (Suri 2011; Duflo et al., 2011).

To better understand why people do not take up loans, we conducted a randomized credit intervention with two components: (1) an information intervention in which we told people about the requirements and procedures to apply for a loan; and (2) an intervention in which we gave people a voucher which lowered the eligibility requirements necessary to begin taking out loans with the Village Bank. Though the vast majority of people took the vouchers when offered them, and $40 \%$ redeemed them, only $3 \%$ of our experimental sample had even started the process of

\footnotetext{
${ }^{7}$ Kneiding and Rosenberg (2008) report a worldwide average APR of 35 percent. The average in Kenya is over 50 percent per year. See Armendáriz and Morduch (2007), Morduch (1999) and Demirguc-Kunt et al. (2009) for more background.

${ }^{8}$ See, for example, de Mel et al. (2008), Fafchamps et al. (2011), McKenzie and Woodruff (2008). For Western Kenya, see Kremer et al. (2011) and Dupas and Robinson (2009).
} 
applying for a loan at the time of writing (6 months after the credit information and voucher interventions). Evidence from qualitative surveys on barriers to borrowing suggests that the fear of losing one's collateral if one cannot repay the loan is the primary deterrent. These results are in line with numerous recent studies in microfinance which show limited demand for microcredit at market rates (i.e. Johnston and Morduch 2008, Banerjee et al 2010, Crépon et al. 2011). They are also roughly consistent with a recent informational experiment in Sri Lanka which found that only $10 \%$ of entrepreneurs who were given information about credit options took out loans (de Mel, McKenzie and Woodruff, 2009).

Overall, our data reveal a number of challenges with the current supply of financial services. Simply expanding those existing services is not likely to massively increase formal banking use among the majority of the poor unless quality can be ensured, fees can be made affordable, and trust issues are addressed. Our results also suggest that marketing could be improved - a large percentage of people lack even basic information about banking options.

Note that while our results are based on two particular banks in one part of Kenya, and concern "classical" banking services rather than agent- or mobile phone-based banking, the general takeaway is that service quality, fees, and trust are important and often overlooked factors. Even MPesa, Safaricom's mobile money network in Kenya and arguably the most developed mobile money product in the world, is ultimately similar in structure to the banks we study here - people must still make deposits and withdrawals in person, in cash, and the fees are substantial. Moreover, M-Pesa, as it is currently constituted, cannot function well as a bank. To guarantee solvency, Safaricom requires agents to pay in advance for any mobile money they purchase. Safaricom then holds this money in bank accounts with several large commercial banks, and gives all interest to charity (Jack and Suri 2011). Clearly, M-Pesa cannot lower fees unless it can invest its deposits for profit - which, in turn, will likely require some form of regulation (for instance, deposit insurance) if people are to trust money with it. ${ }^{9}$ On top of this, banks would lobby vociferously to prevent a new entrant into the banking sector - see Mas and Radcliffe (2010) for evidence on this in regards to M-Pesa in Kenya. Given this, it seems that the most likely future for mobile banking is as a platform through which people can transfer money into an account in a formal bank. ${ }^{10}$ Thus, the issues we raise here remain quite pertinent to mobile banking as well.

Our finding that a non-negligible proportion of people distrust banks generally is somewhat surprising, since the banking sector in Kenya has been relatively stable for some time: while Kenya has had a number of banking scandals, many of these were in the 1980s and 1990s (Central Bank of Kenya, 2009), and many involved non-bank financial institutions such as Savings and Credit Cooperations (SACCOs). However, even though the number of bank scandals have been limited in recent years, it is likely that other non-bank related financial scandals have made people wary,

\footnotetext{
${ }^{9}$ Of course, some countries may not require even banks to have deposit insurance, which will create a host of other problems. See Demirgüç-Kunt et al. (2005) which shows that deposit insurance in Africa lags behind other regions.

${ }^{10}$ Safaricom has recently entered into a partnership with a bank to link the M-Pesa account to a formal bank account through the M-Kesho service (Opiyo 2010). Since then, other banks are developing similar services allowing customers to manage their accounts using MPesa.
} 
especially of the Village Bank for which deposits are not insured by the central government. For example, Kenya has had a number of very high-profile pyramid schemes in which an estimated 148,000 people had invested over $\$ 90$ million (Ministry of Co-operative Development and Marketing, 2009). Both Kenya and neighboring Tanzania have also had high-level scandals which ultimately forced their respective Central Bank Governors to step down. Such scandals might quite naturally cause general mistrust of financial institutions. Our results indicate that, once established, such mistrust sticks for a very long time, and limits the extent to which people seek out information about available financial services, even decades later. This suggests that any effort to expand financial access, if it is to successfully achieve financial inclusion, needs to include an important communication component in order to bring awareness of the various options available as well as the regulation around them (especially deposit insurance).

\section{Background Information on Rural Banking}

\subsection{Financial Institutions in our Study Area}

Our data comes from farming villages located near three market centers in Western Province, Kenya. For confidentiality purposes we call these three market centers A, B and C. Two separate financial institutions operate in this area, a Village Bank and a Commercial Bank.

The Village Bank is a community-owned and operated entity that receives support from a local microfinance institution (MFI). Deposits in the bank are not insured by the Central Bank (though the bank does purchase a limited amount of private insurance), and the Village Bank is classified as a Non-Bank Financial Institution. The Village Bank has three branches in our study area. The main branch is located in market A and opened in 2000. There is a smaller branch in market B which opened in 2008, and a part-time branch in market C which opened in September 2009. Branch $\mathrm{C}$ only handles account opening, loan applications and deposits (withdrawals can be made at either of the other two branches, each a bit over $11 \mathrm{~km}$ away). The branches in markets A and B are open Monday through Friday from 8:30 AM to 4 PM, and on Saturdays from 8 AM to 1 PM. The branch in market $\mathrm{C}$ is only open Monday, Wednesday and Friday from 9 AM to 4 PM.

The second local financial institution, the Commercial Bank, is a small branch of a large corporate bank. The branch has an ATM through which people can make deposits and withdrawals at any time and a small staff which assists with these transactions (as well as with account opening and loan applications) during normal business hours (Monday through Friday from 8:30 AM to $4 \mathrm{PM}$ and Saturday from $8 \mathrm{AM}$ to $12 \mathrm{PM}$ ). The main, full-service branch, where tellers process loan applications and handle transactions, is located in a town about $30 \mathrm{~km}$ away. Deposits in the Commercial Bank are insured.

\subsubsection{Savings Products}

The Village Bank offers just one type of savings account, which does not pay interest. At the time this project started, opening an account at the Village Bank cost 300 Kenyan shillings (Ksh). All 
accounts must also hold a $100 \mathrm{Ksh}$ minimum balance making the total account opening fee 400 Ksh, or about $\$ 4.25$ US at the current exchange rate. Deposits are free and there are no monthly fees, but there is a fee to make withdrawals. ${ }^{11}$ No ATM services are available, so savings are illiquid beyond the opening hours mentioned above.

The basic savings account at the Commercial Bank has no account opening fee but a $200 \mathrm{Ksh}$ (\$2.10 US) minimum balance requirement. ${ }^{12}$ The account comes with a free ATM card. The bank charges $30 \mathrm{Ksh}(\$ 0.32)$ for withdrawals of any size from the ATM, and $100 \mathrm{Ksh}$ (\$1.05 US) for withdrawals of any size made with at an urban branch. The account pays no interest unless the customer maintains a balance of $20,000 \mathrm{Ksh}(\$ 210 \mathrm{US})$ for at least a 3 -month period, in which case interest is paid. ${ }^{13}$

A final way that people in the study area can potentially save is through mobile money, as there are a number of mobile money agents in the area. Mobile money is much more commonly used for transfers than for savings, however, for several reasons. First and most obviously, people need to have access to a cell phone (and only $47 \%$ of households in our census have a phone). Second, it is not always possible to withdraw money immediately. On the main mobile money network (M-Pesa), the currency of mobile money is "e-float." The agent holds a balance of e-float on his own cell phone and must decide how much cash to hold to pay out withdrawals. If the agent has a large number of withdrawals on a given day, he may lack the liquidity to cover them all. On the other hand, if there are many deposits, the agent may have no e-float left to sell to allow deposits. These sorts of problems are cited as a drawback by many respondents in our sample. In addition, M-Pesa markets itself as a money transfer, rather than savings, product. Finally, withdrawal fees are substantial (though this is true of both of the banks in our study as well). ${ }^{14}$

\subsubsection{Credit Products}

While both the Village Bank and the Commercial Bank offer credit products, the terms for borrowing vary quite a bit across the two institutions. The Village Bank, like many MFIs, requires the formation of a group of at least 5 people who approve the purpose and amount of each other's loans, and who serve as mutual guarantors. To take out a loan, borrowers must purchase a share (valued at $300 \mathrm{Ksh}$ each, or $\$ 3.20 \mathrm{US}$ ) in the bank. Borrowers are then eligible to borrow up to four times the value of shares owned. In addition, the bank requires borrowers to attend several training sessions on loan management.

The Village Bank offers several different types of loans, most at interest rates between 1.25 and 1.5 percent per month (16-19.5\% APR). Loans are to be used for business purchases, with the exception of a loan for emergencies which features a higher interest rate $(2.25 \%$ per month).The Commercial Bank grants microloans for existing businesses to individuals who have had an account

\footnotetext{
${ }^{11}$ The withdrawal fee is $10 \mathrm{Ksh}(\$ 0.10)$ to withdraw amounts under $1,000 \mathrm{Ksh}(\$ 10.50), 20 \mathrm{Ksh}(\$ 0.21)$ to withdraw amounts between 1,000 and 4,999Ksh $(\$ 53)$, and $100 \mathrm{Ksh}(\$ 1.05)$ for amounts of 5,000Ksh or higher.

${ }^{12}$ The Commercial Bank also offers a youth savings account with a smaller minimum balance requirement.

${ }^{13}$ The interest rate is variable, ranging from $2-4 \%$ within the study period.

${ }^{14}$ See Jack and Suri (2011) and Mbiti and Weil (2011) for more detail on these issues.
} 
at the Commercial Bank or with another Commercial Bank for at least 3 months. Prospective borrowers must also be visited by a loan officer to assess the state of the business. Loans must be repaid within 6 months, with an interest a rate of $1.5 \%$ per month. Two guarantors and full collateral are required for each loan ${ }^{15}$

\section{$2.2 \quad$ History of Financial Scandals}

One of the key results of this study is that the level of interest and trust in financial institutions is quite low among rural households. This finding is not particularly surprising when it applies to nonregulated financial institutions, such as the Village Bank that operates in our study area, or Savings and Credit Cooperatives (SACCOs), which have somewhat charged history of financial scandals, up to the present day. In fact, the Village Bank in our study area suffered a financial scandal at its main branch (in market A) shortly after we started working in the area. The branch manager was fired for embezzlement, resulting in a months-long liquidity crisis during which existing customers were barred from withdrawing funds over $\$ 10.50$ a day per customer. During the crisis, the satellite branch in market $\mathrm{C}$ was temporarily closed. Though nobody has officially lost deposits, liquidity remains a problem to this day.

What is more surprising is that trust in fully regulated financial institutions also appears relatively low, despite the fact that Kenya has had relatively few scandals specific to the regulated banking sector in recent years. Why have rural populations not embraced banks that offer insured deposits? One hypothesis is that they do not make a clear distinction between regulated and unregulated institutions, and their somewhat well-founded mistrust of Village Banks and SACCOs expands to the banking sector more generally. Another hypothesis is that they remember the various banking crises that Kenya had in previous decades, particularly from 1983 until the late 1990s. These crises were dramatic and hugely costly. For instance, 11 banks were put under liquidation in 1993 alone (Central Bank of Kenya, 2009). Outright fraud during crises between 1993 and 1995 was estimated to cost 3.8\% of GDP (Economist Intelligence Unit, 1995), and affected 30\% of total bank financial assets (Daumont et al. 2004). While many of these crises occurred a number of years ago, it's likely that memory of them continues to have some effect on perceptions.

Another reason that people might be wary is that Kenya has had a number of pyramid schemes and other scams, including a number in recent years. The problem was so severe that the Government put together a Task Force on Pyramid Schemes in 2009. The final report of that Task Force reported that over 148,000 people had invested over $\$ 90$ million in various pyramid schemes. The largest of these (DECI) had over 93,000 investors alone (Ministry of Co-Operative Development and Marketing, 2009). Other scandals have involved corruption at very high levels. In the early 1990s, a number of government officials, including the Governor of the Central Bank, were implicated in the notorious "Goldenberg" scandal, which led to a minimum of $\$ 600$ million in fraud (Warutere 2005).

\footnotetext{
${ }^{15}$ Besides these two banks, credit is available from a third institution which until recently did not take deposits. However, that organization lends only to women with licensed businesses.
} 
Note that these issues are not specific to Kenya. A number of other African countries had major banking scandals during the 1980s and 1990s (Caprio and Klingebiel, 1997; Brownbridge, 1998), several of which cost over 10\% of GDP (Daumont et al., 2004). Within East Africa, Uganda had a banking crisis in which four commercial banks, holding over $12 \%$ of the nation's deposits, collapsed over just 13 months in 1998 and 1999 (Habyarimana, 2005; Brownbridge 2002). Tanzania had a major banking crisis in the late 1980s in which government-owned banks (accounting for 95\% of total bank assets) became insolvent. Total estimated losses from this crisis were equivalent to about $10 \%$ of GDP (Daumont et al. 2004). Also in Tanzania, a $\$ 120$ million banking scandal in 2005 led to the firing of the Governor of the Central Bank (BBC, 2008).

\section{Study Sample, Design and Data}

\subsection{Sample}

We first conducted a census of all households living within a 4 kilometer radius of the three market centers in our study area. The census survey collected information on demographic characteristics of the household, sources of income, as well as access to financial services, knowledge and perceptions of available financial services, and saving practices more generally.

A total of 1,898 households were surveyed during the census exercise. Table 1 presents some summary statistics on those households. Panel A presents demographic information. The average household had just below 6 members. Only a few households (11\%) did not have a female head living in the homestead, but around $31 \%$ of households did not have a male head living in the homestead. ${ }^{16}$ Polygamy is still somewhat prevalent $-8 \%$ of households are polygamous. The average household in the study area owned just under two acres of land, and had just above 4,000 Ksh (\$42) in animal assets. Almost half (47\%) of households owned a cell phone.

Panel B of Table 1 presents statistics on access to banking services. Only $20 \%$ of households had a member with a bank account, despite the fact that the average distance to the closest deposittaking financial institution is only 1.6 kilometers, suggesting that physical access is unlikely to be the barrier.

Table 2 presents statistics at the individual level, separately for women (Panel A) and men (Panel B). Average educational attainment is relatively low, with just about 6 years of education for women and 8 years for men. Sixty-five percent of women and $90 \%$ of men were literate. Almost three-quarters of women reported farming as their primary activity, while only a little over a third of men did. Own enterprise was the primary occupation of $19 \%$ of women and $36 \%$ of men. The remainder worked in physical day labor (mostly associated with agriculture), worked for a wage, or had no job. Table 2 also includes individual-level statistics on access to banking. While $21 \%$ of men had a bank account, only $10 \%$ of women did.

To construct a sample, the primary eligibility criterion was that nobody in the household had a

\footnotetext{
${ }^{16}$ This is the result of two main factors: (1) it is much less common for a widow to remarry than it is for a widower; and (2) some men leave their family behind to work in urban areas.
} 
bank account. However, we also decided to exclude all polygamous households and all households with no female head. The rationale for doing this is that those two categories of households are likely very different from others, yet they are too few of them to do subgroup analysis. In the case of polygamous households, another reason is that measuring expenditures and savings in such households is difficult and time-intensive.

Given this eligibility criteria, 989 of the 1,898 households in the census were selected to participate in the randomized experiment, comprising 1,565 individuals. As is to be expected, households in the experimental sample are poorer, less educated, and more likely to be farmers than other households (see Column 2 in Tables 1 and 2).

\subsection{Experimental Design}

\subsubsection{Savings Experiment}

After constructing the sample, we randomly selected individuals for the savings intervention. Randomization was done at the individual (rather than household) level, stratified by household composition (single female-headed or dual-headed), primary occupation, and market center.

The savings intervention was rolled out between May and June 2010. Those individuals who were selected for this intervention received a nominal, non-transferable voucher for a free savings account. For those living within 4 kilometers of Market A (where the Commercial Bank has an ATM), the voucher was redeemable at either the Village Bank or the Commercial Bank. For everybody else, the voucher was for the Village Bank only. The experiment made it financially costless to open an account: the vouchers covered all account-opening fees (where applicable), including the minimum balance requirement.

The vouchers were delivered to people in their homes. During that visit, individuals received information on how the bank and the account work, and when and how to redeem the voucher. ${ }^{17}$

Among households with no male head, 50\% were randomly selected to receive an account voucher, which was given to the female head. Among households with both a female and a male head, $20 \%$ received no voucher, $30 \%$ received two vouchers (one for each head), and $50 \%$ received one voucher (in $25 \%$ of households, the male received the voucher; in the other $25 \%$, only the female received the voucher). In total, $55 \%$ of the sample was selected to receive vouchers.

\subsubsection{Credit Experiment}

In February 2011, a second randomization was conducted to lower informational and financial barriers to credit. The intervention differed slightly according to whether individuals had received the savings intervention 9 months earlier.

Among those who had not received the savings intervention, half were randomly selected to receive information about local credit opportunities. Trained staff visited those individuals at their

\footnotetext{
${ }^{17}$ The vouchers expired after 2 weeks. In practice, most of those who redeemed did so immediately. Commercial Bank customers had to visit the branch twice, once to redeem the voucher and again two weeks later in order to pick up their ATM cards and receive training in their use.
} 
home and delivered a detailed script explaining the rules and procedures for obtaining a loan from either of the two local institutions. No financial assistance was given, however.

Among those who had received the savings intervention, half were selected to receive the same financial information script as above. However, they were also given a voucher redeemable for one free share at the Village Bank (valued at $300 \mathrm{Ksh}$, or $\$ 3.20$ ). As discussed in Section 2.1.2, one of the requirements for getting a loan from the Village Bank is that an individual must purchase a share (in addition to having a bank account). In particular, the maximum amount that anyone can borrow is four times the amount of share capital they own. While the share is not the only requirement to get a loan (in particular, people must form a group with four other bank clients who approve their loan and act as guarantors), getting a free share does lower the barrier to getting a loan.

\subsection{Data}

We use three main sources of data in this project. First, we have background information (described above) from the census. Second, we have administrative data on deposits, withdrawals and loan applications from the bank. All study participants that opened an account agreed to sign a waiver allowing their bank to release their bank statements to the research team. We use these bank statements to monitor the saving activity as well as the credit history of our restricted experimental sample. Third, a semi-structured survey was administered to a randomly selected half of the restricted experimental sample after 9 months. The survey asked respondents open-ended questions about their current savings practices, perceived barriers to saving, and perceptions of the various saving mechanisms available to them. For those who had received an account voucher but had not redeemed it, the survey also asked why they had not opened an account. The survey also included a number of questions about familiarity with and interest in local credit options.

\section{Rural Households and their Money: A Snapshot}

In Tables 3 and 4 we present information from the census to show how rural households in the study area save. Table 3 presents means at the household level, separately by household type. Table 4 present means at the individual level, separately by gender.

The first striking observation in Table 3 is the fact that access to formal saving services is very limited. Among the $20 \%$ of households which have at least one family member with a savings account, only about $12 \%$ have accounts in a commercial bank (this includes all commercial banks in Kenya, not just the bank which participated in the experiment), $8 \%$ in the Village Bank that participated in the experiment, and $3 \%$ in the post office savings bank. Nobody saves in a microfinance institution. Note that some households have multiple accounts, so these categories are not exclusive.

Interestingly, $25 \%$ of households have a mobile money account. However, most Kenyan households do not currently save in such accounts and instead use them only for transfers (Mbiti and 
Weil, 2011). ${ }^{18}$ Nevertheless, the relatively high penetration of such accounts in even very rural areas is potentially very promising.

In contrast to the low rates of participation in formal savings, savings through informal mechanisms is quite important- $56 \%$ of households have at least one member who participates in a ROSCA. ${ }^{19}$ A ROSCA (Rotating Savings and Credit Association) is a savings group (composed of 10 to 20 members, typically) that meets on a regular basis; at each meeting, group members make a fixed, mandatory contribution which goes into a "pot" that is then assigned to one of the members. Each member gets the pot in turn. A ROSCA cycle thus requires as many meetings as there are members. Once a cycle is complete, a new cycle can start. Though the structure of ROSCAs varies from place to place, most ROSCAs in this part of Kenya use a predetermined order to allocate the savings pot. Many households (52\% of the population) also save in animals, which can be used both as a form of savings and as productive assets.

The amounts saved in ROSCAs and animals are not trivial- the average household reports saving over 7,200 Ksh in ROSCAs (\$76 US) over the past year and owning about 4,300 Ksh (\$45 US) worth of animals. These two forms of informal savings are relatively illiquid, however. Selling animals quickly in response to negative income shocks is not easy, especially if the shock is an aggregate shock at the community level (since the market may be flooded with people selling animals at that time). In the case of ROSCAs, since they typically have a predetermined order, it is impossible to access the money immediately if an emergency comes up. Thus, a more liquid savings option (such as a bank account) could still be useful to people.

The breakdown by household type in Panels B and C of Table 3 shows that female-headed households are much less likely to be banked than dual-headed households (9\% vs. 25\%). They are also less likely to use informal saving mechanisms, suggesting that their overall saving rate is lower. The individual-level means presented in Table 4 suggest that this gap between household types is essentially driven by a gender divide: only $10 \%$ of women have banking accounts, compared to $21 \%$ of men. Similarly, only $12 \%$ of women have mobile money accounts, compared to $28 \%$ of men.

There are also major differences between those who are primarily farmers and those who are not. We present the statistics disaggregated by gender and farming status in Appendix Table A1. Only $8 \%$ of farmers have savings accounts, compared to $23 \%$ of non-farmers. Most striking is that only $6 \%$ of female farmers have accounts. Farmers are also much less likely to participate in a ROSCA or have a mobile money account.

Given the low rate of banking, and the fact that the most common informal saving alternatives are relatively illiquid, a key question is how people deal with emergencies that require immediate liquidity. To shed some light on this issue, our census survey asked people "If you absolutely needed $1,000 \mathrm{Ksh}(\$ 10.5 \mathrm{US})$ right now, where would you get the money?" We allowed people to list as

\footnotetext{
${ }^{18}$ As discussed in the introduction, formal banks in Kenya have lobbied against the entry of M-Pesa. In part to avoid this controversy, M-Pesa markets itself as a service for transferring money and not for saving. This (along with the withdrawal fees) is likely a big reason that people do not much use M-Pesa as a savings vehicle.

${ }^{19}$ Besley, Coate and Loury (1993), Anderson and Baland (2002) and Gugerty (2007) discuss various reasons why so many people in developing countries participate in ROSCAs.
} 
many sources as they wanted (so that the categories are not exclusive). The results are presented in Table 5. We find that only $13 \%$ of people would be able to get even part of the money from savings. Most people would ask others for help, while others would have to sell a household asset or work more. Although it's conceivable that people could fully make up for a 1,000 Ksh shortfall by relying on others, nearly every study of inter-household risk coping suggests that this is unlikely. Thus, it seems likely that increasing savings would better allow people to cope with shocks.

\section{Understanding Low Levels of Formal Banking}

This section discusses factors which partially explain the low observed rate of formal banking. We start by describing our baseline survey evidence. We find that at the time our study began people knew very little about local financial institutions, suggesting that earlier marketing activities by these financial institutions, if any, had been mostly unsuccessful. We then present evidence from the randomized savings experiment. Overall, while we find that reducing the account opening fees and minimizing the hassle of opening an account did induce a minority to start saving in the bank, we find that most people did not use their accounts. Survey evidence suggests that the major reasons people did not use the bank is that they were concerned about high withdrawal fees and poor service, and that they did not trust their money with the bank. Note that given our experimental design, it is not surprising that distance to a local banking option does not appear as a major factor, as the sample was drawn from villages within walking distance of the bank.

\subsection{Survey Evidence: Baseline Interviews}

Table 6 presents data from the census on knowledge of and trust in the Village Bank, separately by branch. At the time of the census, the Village Bank had been established in market center A for nearly 10 years, in market center B for about 18 months, and in market center $\mathrm{C}$ for 10 months. Despite this, only $64 \%$ of household heads in markets $\mathrm{A}$ and $\mathrm{B}$, and $51 \%$ in market $\mathrm{C}$, had ever heard of the Village Bank. Even those who had heard of the bank did not know enough about it to have an opinion about it. Thus, when those who had at least heard of the Village Bank were asked if they would trust the bank with their money, $43 \%$ said they didn't know enough about the bank to know. Around $49 \%$ said they would trust the bank, while the remaining $8 \%$ said they would not. The main reasons for not trusting the bank were lack of familiarity and being worried about embezzlement of funds.

Table 7 addresses those in the experimental sample, who were all unbanked at the time of the census, and to whom a slightly more detailed survey was administered. In this sample, we asked about knowledge of both the Village Bank and the Commercial Bank. Unsurprisingly, familiarity with local financial institutions is lower among these unbanked individuals than in the full census sample. Only about half of household heads had heard of the Village Bank across the three market centers, though awareness was slightly higher in Market A (where the Village Bank had been established for longer), and lower in Market $\mathrm{C}$ (where the Village Bank had only recently started 
a deposit-only branch). Very few individuals knew the details of the services offered by the Village Bank, however - only $8 \%$ of those who had heard of the bank knew the cost of opening an account.

Despite the fact that the Commercial Bank, located in market A, had only opened in late 2008

(8 years after the Village Bank), by 2009 it had the same level of name recognition as the Village Bank. Just as with the Village Bank, however, people knew very little about the products offered at the Commercial Bank: none of the respondents knew that accounts were free (with only a minimum balance requirement).

Though people do not know much about either bank, most people tend to prefer the Commercial Bank (likely because it is a large, well-established bank with a national presence). When asked which institution they would prefer to have an account in, close to two-thirds of respondents said they would choose the Commercial Bank over the Village Bank.

\subsection{Experimental Evidence}

The randomized savings experiment allows us to test the extent to which eliminating opening fees, facilitating account opening, and providing information can increase access to formal banking. Table 8 presents figures on take-up of the experimental offer of a free bank account. A relatively large fraction of individuals elected to open an account: overall take-up was $62 \%$. In market A, where both banks are available, the Commercial Bank was the favorite choice: $43 \%$ of people opened an account at the Commercial Bank, compared to only $17 \%$ at the Village Bank. Across the branches, take-up was lowest in market $\mathrm{C}$, where the Village Bank only offers partial service.

However, many of those who opened accounts did not actively use them. In Table 8, we define an account as "active" if the respondent made at least two deposits in the year following the account opening date. We find that only $28 \%$ of opened accounts were active. Since only $62 \%$ of people even opened accounts, this means that the overall usage rate was only $0.28 \times 0.62=18 \%$. In Table 9, we show the results separately for men and women (pooling all the market centers together). While women were slightly less likely to open accounts than men, they were 10 percentage points more likely to actively use the account if they opened one. Overall, the active take-up rate was thus higher among women than men (19.7\% versus $14.0 \%)$, but still relatively modest among both groups. Overall, these results suggest that entry costs - be it the cost of acquiring information, the opening fees (including minimum balance requirement) or the administrative hassle of opening an account - explain only about $1 / 5$ th of the low banking rates observed in our study area.

\subsection{More Survey Evidence: Debriefing Interviews}

To understand what other supply factors explain the relatively low demand for formal banking we observe once the entry costs were experimentally removed, we asked respondents, in an openended way, what their concerns were with the various saving mechanisms available to them. We asked these questions to a random subset of our restricted experimental sample. The results are presented in Table 10. We present the results separately for those in the control group (who did not receive information and assistance with account opening), those in the treatment group who did not 
actively use the account (whom we call non-compliers), and those in the treatment group who did use the accounts (whom we call compliers). We present results for the three formal and quasi-formal banking options available: the Commercial Bank, the Village Bank, and Mobile Money.

The main concerns raised with formal banks are transaction fees, unreliability, and risk of embezzlement. The relative importance of these concerns varies substantially between the two financial institutions in our study area. Transaction fees are the primary concern with the Commercial Bank, which charges a flat fixed fee of $30 \mathrm{Ksh}$ per withdrawal at the ATM, making it very costly to make small withdrawals. While these withdrawal fees could act as a commitment device to not withdraw money until a relatively large lump sum has been saved, they can also deter people from saving in the account if they anticipate needing small sums to deal with emergencies as they arise. This is in line with a related study we conducted in this part of Kenya, in which we find that the cost of limiting liquidity exceeds its benefit for many people (Dupas and Robinson, 2011).

For the Village Bank, while fees remain a major concern, substantial fractions of people also report unreliability and risk of embezzlement as problems. Among the non-compliers, 37\% cite unreliability and $24 \%$ cite risk of embezzlement, suggesting that many of those who did not actively take-up Village Banking thought service quality was poor or lacked trust in the institution.

In regards to mobile banking, the most common concerns are that it requires owning a cell phone and that there are network or liquidity issues (i.e. the agent runs out of "e-float", to pay out withdrawals). Fees are less of a concern for mobile money banking than for formal banks, even though in practice the fees associated with mobile money fall somewhere in between the fees charged at the Village Bank and those charged at the Commercial Bank. Notably, trust in mobile banking is extremely high (another promising sign if mobile money is eventually to be mobilized for savings as well as transfers).

Table 11 provides further qualitative evidence on these issues by disaggregating results by market center. Recall that there was a withdrawal freeze in the wake of an embezzlement scandal in Market A and that the service in Market $\mathrm{C}$ is spotty, so we might expect people to trust the Village Bank least in Market A and find it most unreliable in Market C. Interestingly, Table 11 shows that this is true only of people who actively used the accounts. Though the sample of people who use their account is obviously selected, one interpretation of these findings is that people's experience with the Village Bank reinforced the mistrust in the institution.

Table 11 also reports responses to a question in which we asked people for their preferred savings options. All in all, when asked what their preferred savings mechanism would be if they could choose, over $40 \%$ of respondents answered "a commercial bank." A sizeable fraction also reported the Village Bank. As expected, this share is higher in the control and compliers groups than in the non-compliers group. Somewhat surprisingly, mobile money banking was the least favorite mechanism, behind grain storage and ROSCA participation. In fact, almost $40 \%$ of the control group reported informal options (animals, ROSCAs, or saving in grain) as their preferred saving tool. Given the risks associated with these informal saving mechanisms, the fact that they remain preferred is suggestive that the formal products being offered are insufficient for many 
people. This is consistent with the finding that close to a quarter of respondents said they had been discouraged to open a bank account by a friend.

\subsection{Open questions}

The evidence presented thus far has focused on supply issues. These issues only partially explain the low formal savings rates we observe in our experiment, however. Many of those in the treatment group who do not list trust, fees, or reliability as concerns still do not use the accounts. When asked directly what keeps them from saving, many of them say that their expenses are too high or that their income is simply too low for them to save at all. However, it is hard to know how to interpret these responses. Existing evidence strongly suggests that even extremely poor people can save. For instance, research in the Gambia (Shipton, 1990) and Bangladesh, India, and South Africa (Collins et al., 2009) demonstrates that poor households do find ways to save, albeit often through informal mechanisms. Moreover, Banerjee and Duflo (2007) find that even among the poorest households

- those living at or under $\$ 1$ per person per day - the majority don’t exhaust all their income on basic necessities.

Ultimately, the low take-up rate in this study begs the question: is a savings account in a bank relatively far from home well-tailored for people who can only save in very small increments? Providing a more convenient place to save, or stronger incentives to make deposits, may be more effective. For example, in previous work, we find that people save quite readily if provided with a lock box and key which they can keep at home (Dupas and Robinson, 2011). Furthermore, providing people with a credit incentive to make deposits, and social pressure to continue making them, was extremely effective in mobilizing savings. Similarly, Duflo et al. (2011) find that providing people with small incentives to set aside money for fertilizer when people have money (after harvest) increases fertilizer investment. Other recent papers have shown how prompting people to save (Atkinson et al., 2010) or providing people with reminders to save can also be quite effective (Kast et al 2010; Karlan et al. 2011).

Indeed, in countries like the US, where many transactions are conducted electronically, it is has been well documented that savings can be most effectively mobilized when they are "unseen," for example when wage increases are automatically put into a savings account (Thaler and Benartzi, 2004) or when people are automatically opt in to a certain 401(k) savings level (Carroll et al., 2009). Designing such products in a much more cash-based economy may be difficult, but is worth exploring. In fact, the value of mobile money (such as M-Pesa in Kenya) may be largely in making savings more electronic; it might be less costly, both in terms of transportation and time, to transfer an electronic balance to a linked savings account than to physically take cash to the bank during operating hours. It may also be less painful psychologically to devote electronic money to savings rather than to physically put cash into a savings account. 


\section{Understanding Low Borrowing Rates}

While much of our focus has been on savings, the flipside of savings is credit. Returns to capital have been estimated to be quite high in the study area (as discussed in footnote 12), higher than the APR on loans offered by the two financial institutions (which vary from 16-19.5 percent APR). What keeps people from taking out such loans and reaping high returns?

We examine this issue in Tables 12-14. To start, Table 12 describes familiarity with local credit options among our restricted experimental sample of unbanked households. As with savings, people have very limited information about credit options. Only $64 \%$ think there is a local credit option and only $38 \%$ (41\%) correctly identified the Village Bank (Commercial Bank), respectively, as a credit option. Only $15 \%$ said that they knew the procedure to get a loan; interestingly, only $7 \%$ could correctly describe the procedure when asked. ${ }^{20}$

To gauge potential interest in loans, we asked people if they were interested in a loan at $1.5 \%$ monthly interest, with or without collateral requirements. While $74 \%$ said that they were interested if no collateral was required, this dropped to only $32 \%$ with collateral. We also asked people if they thought that they could qualify for a loan, and $37 \%$ said yes. Yet only $6 \%$ had ever applied for loan.

Given this low level of information, we implemented an intervention to improve information and access to credit (the details are presented in Section 3.2.2). We present two sets of results of this intervention. First, in Table 13, we report the answers to questions we asked participants immediately after they received detailed information about local credit opportunities. While a majority of people were interested in a loan at the Village Bank, far fewer were interested at the Commercial Bank. This is likely primarily due to the fact that the Commercial Bank only lends to people with an existing business, and as shown in Table 2 , only $15 \%$ of women and $36 \%$ of men in our restricted experimental sample had a business at baseline (farming is not considered a business by the bank). What's more, most of those have a very small market vending business with very low levels of working capital, and they would most likely not quality for a loan from the Commercial Bank in any case. It is also likely that people perceive it as more difficult to qualify for a loan from the Commercial Bank even aside from the business requirement.

Among those interested in borrowing, we asked what they would want to borrow for. Few people were interested in loans for small investments like agricultural inputs. People were much more likely to report wanting to start a business or adding to business inventory with a loan. Whether these types of goals are feasible for such borrowers is an open question.

The second set of results from the experimental credit intervention is presented in Table 14, and concerns the take-up of the "share capital" voucher we gave to a random subset of those who had already been offered an account voucher. By redeeming this voucher, people would be credited with one Village Bank share (valued at $300 \mathrm{Ksh}$ ) and thus be eligible to borrow up to four times the value of the share $(1,200 \mathrm{Ksh})$. Note, however, that this is much smaller than the median desired

\footnotetext{
${ }^{20}$ As shown in Appendix Table A2, these levels are even lower among farmers.
} 
loan size listed in Table 13, which was 10,000 Ksh. Table 14 shows that, while $87 \%$ accepted the voucher when it was given to them, only $40 \%$ redeemed it, and as of the time of writing (6 months after vouchers had been distributed), only $3 \%$ of individuals had started the process of applying for a loan by making an inquiry, and only 1 person (out of 358) had applied and been granted a loan.

While we have not yet followed up with these individuals directly to ask why they did not end up applying for a loan, we did ask people about concerns about taking out loans at the time the vouchers (and information) were given out. These results are reported in Table 15. Overwhelmingly, people report that they are afraid of losing collateral or that taking out a loan is risky. Thus, even at relatively low interest rates, the fear of losing assets overwhelmed loan demand in our study area. Clearly, this creates a serious problem in generating a market for credit, since the interest rate would have to be much higher if loans were not collateralized.

\section{Conclusion}

Without a safe place to save up money, it may be very difficult for people to take advantage of highreturn investments of many types. Likewise, without a safe place to keep an emergency cash buffer, vulnerability to shocks might be very high. Recognizing this, policymakers and international aid organizations have begun to devote attention to expanding access to financial services in developing countries, especially in rural areas where access continues to be extremely limited. This paper shows that unless serious attention is paid to the reliability and quality of financial services offered, simply expanding access by reducing monetary or time costs will fail to effectively achieve financial inclusion.

Our analysis generates several important prescriptions for effectively expanding financial services to the poor. First, trust is an important reason that people do not use current banking services. Providing stronger consumer protection through tighter regulation and deposit insurance could be very important. Second, many people are uninformed about banking options (in part because they have little or no experience with them). Better marketing from the banks themselves might be warranted. Finally, more attention should be paid to the types of products that banks provide. While basic savings accounts do appear to be useful to a minority, more sophisticated products might be necessary for others (just as they are for many people in developed countries). For example, many people in Kenya save to deal with health emergencies, which are very common. For them, putting money into a bank that does not offer withdrawal services at night or on weekends and that has big withdrawal fees might not be very attractive. Similarly, people whose income is seasonal (such as farmers, who make up the great majority of the rural poor in Sub-Saharan Africa) might benefit from products that provide stronger incentives to save as soon as they have money.

In this sense, it is good news that as many as $18 \%$ of people in our poor, rural sample took up and actively used basic savings accounts when they could access them for free. However, the evidence we presented suggests that this is a lower bound on potential demand for formal saving products. Serious attention should be paid to improving the delivery of financial services - doing 
so could improve the lives of millions of people. 


\section{References}

[1] Allen, Franklin, Elena Carletti, Robert Cull, Jun "QJ" Qian, Lemma Senbet, and Patricio Valenzuela (2011). "Improving Access to Banking: Evidence from Kenya." Working paper.

[2] Anagol, Santosh and Christopher Udry (2006): "The Return to Capital in Ghana." American Economic Review 96(2), 388-393.

[3] Anderson, Siwan and Jean-Marie Baland (2002). "The Economics of Roscas and Intrahousehold Resource Allocation." Quarterly Journal of Economics 117, 963-995.

[4] Aportela, Fernando (1999): "Effects of Financial Access on Savings by Low-Income People. Mimeo, Banco de México.

[5] Armendáriz, Beatriz and Jonathan Morduch (2007).The Economics of Microfinance (2nd Edition). Cambridge, MA: MIT Press.

[6] Ashraf, Nava (2009). "Spousal Control and Intra-Household Decision Making: An Experimental Study in the Philippines." American Economic Review 99, no. 4 (September 2009): 1245-1277.

[7] Ashraf, Nava, Dean Karlan, and Wesley Yin. (2006). "Tying Odysseus to the Mast: Evidence from a Commitment Savings Product in the Philippines." Quarterly Journal of Economics 121, 673-697.

[8] Atkinson, Jesse, Alain de Janvry, Craig McIntosh and Elisabeth Sadoulet (2010). "Creating Incentives To Save Among Microfinance Borrowers: A Behavioral Experiment From Guatemala". Working Paper.

[9] Baland, Jean-Marie, Catherine Guirkinger, and Charlotte Mali (2007). "Pretending to be poor: borrowing to escape forced solidarity in credit cooperatives in Cameroon," forthcoming, Economic Development and Cultural Change.

[10] Banerjee, Abhijit, Duflo, Esther, Rachel Glennerster, and Cynthia Kinnan (2010). "The Miracle of Microfinance? Evidence from a Randomized Evaluation." mimeo, MIT.

[11] Banerjee, Abhijit and Esther Duflo (2007). "The Economic Lives of the Poor". Journal of Economic Perspectives 21, 141-167.

[12] BBC (2008) "Tanzania in bank scandal sacking"BBC News, January 10. http://news.bbc.co.uk/2/hi/africa/7181065.stm

[13] Besley, Timothy, Stephen Coate, and Glenn Loury (1993). "The Economics of Rotating Savings and Credit Associations," American Economic Review, 83(4): 792-810.

[14] Bill and Melinda Gates Foundation (2010). "Melinda Gates Challenges Global Leaders: Create Savings Accounts and Bring Financial Security to the World's 
Poorest." Press Release (November 16). http://www.gatesfoundation.org/pressreleases/Pages/melinda-gates-at-global-savings-forum-101116.aspx.

[15] Brownbridge, Martin (1998) "The Causes of Financial Distress in Local Banks in Africa and Implications for Prudential Policy." UNCTAD Discussion Paper Series, No. 132.

[16] Brownbridge, Martin (2002). "Resolving Bank Failures in Uganda: Policy Lessons from Recent Bank Failures." Development Policy Review 20 (3): 279-29.

[17] Bruhn, Miriam, and Inessa Love (2009). "The economic impact of banking the unbanked: evidence from Mexico". World Bank Policy Research working paper no. 4981.

[18] Burgess, Robin and Rohini Pande (2005). "Do Rural Banks Matter? Evidence from the Indian Social Banking Experiment." American Economic Review 95 (3): 780795 .

[19] Caprio, Gerard, Jr. and Daniela Klingebiel (1997). "Bank Insolvency: Bad Luck, Bad Policy, or Bad Banking?" in M. Bruno and B. Pleskovic, eds., Annual World Bank Conference on Development Economics. Washington, DC: World Bank, pp. 79-104.

[20] Carroll, Gabriel, James J. Choi, David Laibson, BrigittMadrian and Andrew Metrick (2009). "Optimal Defaults and Active Decisions: Theory and Evidence from 401(k) Saving," Quarterly Journal of Economics, 124(4): 1639-74.

[21] Central Bank of Kenya (2009) "About DPF [Deposit Production Fund]." Accessed on August 30, 2011 at: http://www.centralbank.go.ke/dpfb/Default.aspx.

[22] Chaia, Alberto, Aparna Dalal, Tony Goland, Maria Jose Gonzalez, Jonathan Morduch, and Robert Schiff (2009). "Half the World is Unbanked." Financial Access Initiative Framing Note.

[23] Collins, Daryl, Morduch, Jonathan, Rutherford, Stuart, Ruthven, Orlanda (2009). Portfolios of the Poor: How the World's Poor Live on \$2 a Day. Princeton University Press, Princeton.

[24] Crepon, Bruno, Florencia Devoto, Esther Duflo and William Pariente (2011). "Impact of Microcredit in Rural Areas of Morocco: Evidence from a Randomized Evaluation". Mimeo, MIT.

[25] Daumont, Roland, Françoise Le Gall, and François Leroux (2004). "Banking in SubSaharan Africa: What Went Wrong?" IMF Working Paper.

[26] de Mel, Suresh, David McKenzie and Christopher Woodruff (2008). "Returns to Capital in Microenterprises: Evidence from a Field Experiment." Quarterly Journal of Economics 123 (4): 1329-1372. 
[27] de Mel, Suresh, David McKenzie and Christopher Woodruff (2009). "Getting Credit to High Return Microentrepreneurs: The Results of an Information Intervention." Forthcoming, World Bank Economic Review.

[28] Demirgüç-Kunt, Asli, Baybars Karacaovali, and Luc Laeven (2005). "Deposit Insurance around the World: A Comprehensive Database." World Bank Working Paper Series \#3628.

[29] Demirgüç-Kunt, Asli, Robert Cull, and Jonathan Morduch (2009). "Microfinance Meets the Market." Journal of Economic Perspectives 23 (1): 167-192.

[30] Duflo, Esther, Michael Kremer, and Jonathan Robinson (2011). "Nudging Farmers to Use Fertilizer: Theory and Experimental Evidence from Kenya." Forthcoming, American Economic Review.

[31] Dupas, Pascaline and Jonathan Robinson (2009). "Savings Constraints and Microenterprise Development: Evidence from a Field Experiment in Kenya."NBER Working Paper \#14693.

[32] Dupas, Pascaline, and Jonathan Robinson (2011). "Why Don't the Poor Save More? Evidence from Health Savings Experiments.” NBER Working Paper \#17255.

[33] Economist Intelligence Unit (1995). Country Report - Kenya, fourth quarter (Nairobi).

[34] Fafchamps, Marcel, David McKenzie, Simon Quinn, and Christopher Woodruff. (2011). "When is capital enough to get female microenterprises growing? Evidence from a randomized experiment in Ghana." Mimeo, University of Oxford.

[35] Ferreira, Francisco and Norbert Schady (2009). "Aggregate Economic Shocks, Child Schooling, and Child Health." World Bank Research Observer 24 (2): 147-181.

[36] Gugerty, Mary Kay (2007). "You can't save alone: commitment in rotating savings and credit associations in Kenya." Economic Development and Cultural Change 55: 251-282.

[37] Habyarimana, James (2005). "The Benefits of Banking Relationships: Evidence from Uganda's Banking Crisis." Working paper, Georgetown.

[38] Honohan, Patrick (2008). "Cross-Country Variation in Household Access to Financial Services." Journal of Banking and Finance 32 (11): 2493-2500.

[39] Jack, William and Tavneet Suri (2011). "Mobile Money: The Economics of M-PESA." Working paper, Georgetown and MIT.

[40] Johnston, Don Jr. and Jonathan Morduch (2008). "The Unbanked: Evidence from Indonesia." World Bank Economic Review 22 (3): 517-537.

[41] Karlan, Dean and Jonathan Zinman (2010). "Expanding Microenterprise Credit Access: Using Randomized Supply Decisions to Estimate the Impacts in Manila." mimeo, Dartmouth and Yale. 
[42] Karlan, Dean, Margaret McConnell, Sendhil Mullainathan, and Jonathan Zinman (2011). "Getting to the Top of the Mind: How Reminders Increase Saving." Working paper.

[43] Kast, Felipe, Stephan Meier, and Dina Pomeranz (2010). "Under-savers anonymous: Evidence on self-help groups and peer pressure as a savings commitment device." Working paper.

[44] Kendall, Jake, Nataliya Mylenko and Alejandro Ponce (2010)."Measuring Financial Access around the World". World Bank Policy Research Working Paper 5253.

[45] Kneiding, Christoph and Richard Rosenberg (2008). "Variations in Microcredit Interest Rates." CGAP Brief (July).

[46] Kremer, Michael, Jean Lee, Jonathan Robinson and Olga Rostapshova (2011). "The Return to Capital for Small Retailers in Kenya: Evidence from Inventories." Working paper.

[47] Kumar, Anjali, Ajai Nair, Adam Parsons, and Eduardo Urdapilleta (2006). "Expanding Bank Outreach through Retail Partnerships: Correspondent Banking in Brazil." World Bank Working Paper No. 85.

[48] Mas, Ignatio and Dan Radcliffe (2010). "Mobile Payments go Viral: M-PESA in Kenya." Bill and Melinda Gates Foundation.

[49] Mbiti, Isaac and David Weil (2011). "Mobile Banking: The Impact of M-Pesa in Kenya." NBER Working Paper No. 17129.

[50] McKenzie, David and Christopher Woodruff (2008). "Experimental Evidence on Returns to Capital and Access to Finance in Mexico," World Bank Economic Review 22 (3): 457-482.

[51] McKinsey and Company (2010). Global Financial Inclusion. Accessed on August 29, 2011 at: http://www.mckinsey.com/clientservice/Social_Sector/our_practices/ Economic_Development/Knowledge_Highlights/ /media/Reports/SSO/GFI_v13_complete.ashx

[52] Ministry of Co-Operative Development and Marketing [Kenya] (2009). Report of the Taskforce on Pyramid Schemes. Government of Kenya: Nairobi.

[53] Morduch, Jonathan (1999). "The Microfinance Promise." Journal of Economic Literature 37 (4): 159-1614.

[54] Nguyen Tien Hung, G. (2004). "Bank on Wheels." Finance 8 Development (June).

[55] Opiyo, Dave (2010). "Banking via phone made possible." Daily Nation (May 18).

[56] Prina, Sylvia (2011). "Do Simple Savings Accounts Help the Poor to Save? Evidence from a Field Experiment in Nepal". Mimeo, Case Western Reserve University.

[57] Robinson, Jonathan and Ethan Yeh (2011). "Transactional Sex as a Response to Risk in Western Kenya." American Economic Journal: Applied Economics 3 (1): 35-64. 
[58] Rosenzweig, Mark and Kenneth Wolpin (1993), "Credit Market Constraints, Consumption Smoothing, and the Accumulation of Durable Production Assets in LowIncome Countries: Investments in Bullocks in India," Journal of Political Economy 101 (2): 223-244.

[59] Ruiz, Claudia (2010). "From Pawn Shops to Banks: The Impact of Formal Credit on Informal Households." Mimeo, UCLA.

[60] Rutherford, Stuart (2000). The Poor and Their Money. Oxford University Press, New Delhi.

[61] Shipton, Parker (1990), "How Gambians Save -and What Their Strategies Imply for International Aid." Agriculture and Rural Development Department, The World Bank, WPS 395

[62] Stuart, Guy, Michael Ferguson and Monique Cohen (2011). "Cash In, Cash Out: Financial Transactions and Access to Finance in Malawi." Financial Services Assessment Report. Accessed on August 29, 2011 at http://www.fsassessment.umd.edu.

[63] Thaler, R., Benartzi, S. (2004). "Save More Tomorrow: Using Behavioral Economics to Increase Employee Saving". Journal of Political Economy 112, S164-S187.

[64] Thyagarajan, S. and Jayaram Venkatesan (2008). "Cost-Benefit and Usage Behaviour Analysis of No Frills Accounts: A Study Report on Cuddalore District." Working paper, Centre for Micro Finance.

[65] Warutere, P (2005). "The Goldenberg conspiracy: The game of paper gold, money and power." Mars Group Kenya Occasional Paper 117. 


\begin{tabular}{|c|c|c|}
\hline & (1) & (2) \\
\hline & Full Sample & $\begin{array}{c}\text { Restricted Experimental } \\
\text { Sample }\end{array}$ \\
\hline \multicolumn{3}{|l|}{ Panel A. Demographic Information } \\
\hline \multirow[t]{2}{*}{ Total Household size } & 5.83 & 5.67 \\
\hline & $(3.05)$ & $(2.95)$ \\
\hline No Male Head & 0.31 & 0.38 \\
\hline No Female Head & 0.11 & 0.03 \\
\hline Polygamous household & 0.08 & 0.00 \\
\hline \multirow[t]{2}{*}{ Number of children } & 3.38 & 3.34 \\
\hline & $(2.34)$ & $(2.28)$ \\
\hline \multirow[t]{2}{*}{ Household health expenditures last month (in Ksh) } & 683 & 508 \\
\hline & (3058) & $(1502)$ \\
\hline Household treats drinking water with chlorine & 0.43 & 0.39 \\
\hline Iron roof at home & 0.48 & 0.45 \\
\hline Cement floor at home & 0.17 & 0.13 \\
\hline $\mathrm{HH}$ has cell phone & 0.47 & 0.40 \\
\hline \multirow[t]{2}{*}{ Value of physical assets (in Ksh) } & 10482 & 9073 \\
\hline & (9852) & $(8448)$ \\
\hline \multirow[t]{2}{*}{ Value of animals (in Ksh) } & 4142 & 4277 \\
\hline & (9278) & $(9424)$ \\
\hline \multirow[t]{2}{*}{ Land holdings (acres) } & 1.90 & 1.74 \\
\hline & $(2.86)$ & $(1.90)$ \\
\hline \multicolumn{3}{|l|}{ Panel B. Access to Banking } \\
\hline At least one member of household has a bank account & 0.20 & 0.00 \\
\hline \multirow[t]{2}{*}{ Distance to closest deposit-taking branch (in km) } & 1.60 & 1.60 \\
\hline & $(0.74)$ & $(0.71)$ \\
\hline \multirow[t]{2}{*}{ Distance to closest branch offering withdrawals (in km) } & 2.78 & 3.01 \\
\hline & $(2.32)$ & $(2.45)$ \\
\hline \multicolumn{3}{|l|}{ Panel C. Eligibility for Experimental Treatments } \\
\hline Eligible for randomized saving and credit experiments & 0.52 & 1.00 \\
\hline Number of Households & 1898 & 989 \\
\hline
\end{tabular}

Standard deviations in parentheses. The exchange rate at the time of the study was around 80Ksh to US\$1 on average. 
Table 2. Baseline Individual characteristics

\begin{tabular}{|c|c|c|}
\hline & $\begin{array}{c}(1) \\
\text { Full Sample }\end{array}$ & $\begin{array}{c}(2) \\
\text { Restricted Experimental } \\
\text { Sample } \\
\end{array}$ \\
\hline \multicolumn{3}{|l|}{ Panel A. Women } \\
\hline Age & $\begin{array}{c}39.27 \\
(15.98)\end{array}$ & $\begin{array}{c}40.39 \\
(17.02)\end{array}$ \\
\hline Years of education & $\begin{array}{c}6.09 \\
(3.88)\end{array}$ & $\begin{array}{c}5.34 \\
(3.65)\end{array}$ \\
\hline Can write in Swahili ${ }^{1}$ & 0.65 & 0.58 \\
\hline \multicolumn{3}{|l|}{ Primary Occupation: } \\
\hline Farming & 0.72 & 0.78 \\
\hline Own enterprise & 0.19 & 0.15 \\
\hline Physical labor & 0.02 & 0.02 \\
\hline Employee & 0.03 & 0.00 \\
\hline None & 0.05 & 0.05 \\
\hline Has bank account & 0.10 & 0.00 \\
\hline Included in Experimental Sample & 0.56 & 1.00 \\
\hline Number of Women & 1686 & 949 \\
\hline \multicolumn{3}{|l|}{ Panel B. Men } \\
\hline \multirow[t]{2}{*}{ Age } & 41.73 & 40.02 \\
\hline & $(15.28)$ & $(15.33)$ \\
\hline \multirow[t]{2}{*}{ Years of education } & 8.10 & 7.35 \\
\hline & $(3.58)$ & $(3.25)$ \\
\hline Can write in Swahili & 0.90 & 0.90 \\
\hline \multicolumn{3}{|l|}{ Primary Occupation: } \\
\hline Farming & 0.38 & 0.43 \\
\hline Own enterprise & 0.36 & 0.36 \\
\hline Physical labor & 0.10 & 0.11 \\
\hline Employee & 0.10 & 0.05 \\
\hline None & 0.06 & 0.04 \\
\hline Has bank account & 0.21 & 0.02 \\
\hline Included in Experimental Sample & 0.47 & 1.00 \\
\hline Number of Men & 1299 & 606 \\
\hline
\end{tabular}

Standard deviations in parentheses.

${ }^{1}$ We use writing in Swahili as a proxy for literacy because we have fewer observations with data on being able to read in Swahili. Results look very similar with alternate definitions, however. 
Table 3. How do Households Save?

\begin{tabular}{|c|c|c|}
\hline Panel A All Households & All & \# obs \\
\hline \multicolumn{3}{|l|}{ Informal Savings } \\
\hline Owns Animals & 0.50 & 1806 \\
\hline \multirow[t]{2}{*}{ Value of Animals (for those who own) } & 4358 & 1751 \\
\hline & (9469) & \\
\hline Someone in Household Participates in ROSCA & 0.53 & 2984 \\
\hline ROSCA contributions in past year (if any) & 7231 & 924 \\
\hline & $(13121)$ & \\
\hline \multicolumn{3}{|l|}{ Formal Savings } \\
\hline Has Account in Formal Deposit-Taking Institution & 0.20 & 1752 \\
\hline Has Account in Commercial Bank & 0.12 & 1752 \\
\hline Has Account in Post Bank & 0.03 & 1752 \\
\hline Has Account in Village Bank & 0.08 & 1752 \\
\hline Has Account with MFI & 0.00 & 1752 \\
\hline Has Account Elsewhere & 0.03 & 1752 \\
\hline Has Mobile Money Account & 0.25 & 1752 \\
\hline \multicolumn{3}{|l|}{ Panel B. Married Households } \\
\hline \multicolumn{3}{|l|}{ Informal Savings } \\
\hline Owns Animals & 0.52 & 1195 \\
\hline \multirow[t]{2}{*}{ Value of Animals (for those who own) } & 4762 & 1153 \\
\hline & (9944) & \\
\hline Someone in Household Participates in ROSCA & 0.56 & 2388 \\
\hline ROSCA contributions in past year (if any) & 8361 & 675 \\
\hline & $(14812)$ & \\
\hline \multicolumn{3}{|l|}{ Formal Savings } \\
\hline Has Account in Formal Deposit-Taking Institution & 0.25 & 1169 \\
\hline Has Account in Commercial Bank & 0.16 & 1169 \\
\hline Has Account in Post Bank & 0.03 & 1169 \\
\hline Has Account in Village Bank & 0.09 & 1169 \\
\hline Has Account with MFI & 0.00 & 1169 \\
\hline Has Account Elsewhere & 0.04 & 1169 \\
\hline Has Mobile Money Account & 0.32 & 1169 \\
\hline \multicolumn{3}{|l|}{ Panel C. Single Headed Female Households } \\
\hline \multicolumn{3}{|l|}{ Informal Savings } \\
\hline Owns Animals & 0.47 & 501 \\
\hline \multirow[t]{2}{*}{ Value of Animals (for those who own) } & 3637 & 489 \\
\hline & $(8286)$ & \\
\hline Someone in Household Participates in ROSCA & 0.40 & 492 \\
\hline ROSCA contributions in past year (if any) & 4118 & 208 \\
\hline \multicolumn{3}{|l|}{ Formal Savings } \\
\hline Has Account in Formal Deposit-Taking Institution & 0.09 & 478 \\
\hline Has Account in Commercial Bank & 0.04 & 478 \\
\hline Has Account in Post Bank & 0.01 & 478 \\
\hline Has Account in Village Bank & 0.05 & 478 \\
\hline Has Account with MFI & 0.00 & 478 \\
\hline Has Account Elsewhere & 0.01 & 478 \\
\hline Has Mobile Money Account & 0.09 & 478 \\
\hline
\end{tabular}

Data: Full census sample. Standard deviations in parentheses. Monetary values in Kenyan shillings (Ksh). Exchange rate was roughly $80 \mathrm{Ksh}$ to \$1 US during the sample period. 
Table 4. How do Individuals Save?

\begin{tabular}{|c|c|c|}
\hline & All & \# obs \\
\hline \multicolumn{3}{|l|}{ Panel A. All } \\
\hline Participates in ROSCA & 0.41 & 2605 \\
\hline \multirow[t]{2}{*}{ If yes: Number of ROSCAs } & 1.50 & 1079 \\
\hline & $(0.80)$ & \\
\hline \multirow[t]{2}{*}{ If yes: ROSCA contributions in past year (in Ksh) } & 6130 & 1090 \\
\hline & $(10443)$ & \\
\hline Has Account in Formal Deposit-Taking Institution & 0.15 & 2869 \\
\hline Has Account in Commercial Bank & 0.08 & 2869 \\
\hline Has Account in Post Bank & 0.02 & 2869 \\
\hline Has Account in Village Bank & 0.05 & 2869 \\
\hline Has Account with MFI & 0.00 & 2869 \\
\hline Has Account Elsewhere & 0.02 & 2869 \\
\hline Has Mobile Money Account & 0.19 & 2869 \\
\hline \multicolumn{3}{|l|}{ Panel B. Women } \\
\hline Participates in ROSCA & 0.45 & 1608 \\
\hline \multirow[t]{2}{*}{ If yes: Number of ROSCAs } & 1.54 & 725 \\
\hline & $(0.82)$ & \\
\hline \multirow[t]{2}{*}{ If yes: ROSCA contributions in past year (in Ksh) } & 5316 & 723 \\
\hline & $(8272)$ & \\
\hline Has Account in Formal Deposit-Taking Institution & 0.10 & 1640 \\
\hline Has Account in Commercial Bank & 0.04 & 1640 \\
\hline Has Account in Post Bank & 0.01 & 1640 \\
\hline Has Account in Village Bank & 0.05 & 1640 \\
\hline Has Account with MFI & 0.00 & 1640 \\
\hline Has Account Elsewhere & 0.01 & 1640 \\
\hline Has Mobile Money Account & 0.12 & 1640 \\
\hline \multicolumn{3}{|l|}{ Panel C. Men } \\
\hline Participates in ROSCA & 0.36 & 997 \\
\hline \multirow[t]{2}{*}{ If yes: Number of ROSCAs } & 1.42 & 354 \\
\hline & $(0.74)$ & \\
\hline \multirow[t]{2}{*}{ If yes: ROSCA contributions in past year (in Ksh) } & 7733 & 367 \\
\hline & $(13625)$ & \\
\hline Has Account in Formal Deposit-Taking Institution & 0.21 & 1229 \\
\hline Has Account in Commercial Bank & 0.14 & 1229 \\
\hline Has Account in Post Bank & 0.02 & 1229 \\
\hline Has Account in Village Bank & 0.06 & 1229 \\
\hline Has Account with MFI & 0.00 & 1229 \\
\hline Has Account Elsewhere & 0.03 & 1229 \\
\hline Has Mobile Money Account & 0.28 & 1229 \\
\hline
\end{tabular}


Table 5 . If you absolutely needed $1,000 \mathrm{Ksh}$, where would you get the money?

\begin{tabular}{|c|c|c|}
\hline & All & \# obs \\
\hline \multicolumn{3}{|l|}{ Panel A. All } \\
\hline Would use savings & 0.13 & 1984 \\
\hline Would work more & 0.14 & 1984 \\
\hline Spouse would work more & 0.07 & 1984 \\
\hline Would borrow from friend/relative/neighbor & 0.43 & 1984 \\
\hline Would get donations from friend/relative/neighbor & 0.13 & 1984 \\
\hline Would get a loan from ROSCA & 0.06 & 1984 \\
\hline Would sell household asset / animal / land & 0.13 & 1984 \\
\hline Would sell business asset & 0.01 & 1984 \\
\hline Would sell agricultural product & 0.14 & 1984 \\
\hline Other & 0.08 & 1984 \\
\hline \multicolumn{3}{|l|}{ Panel B. Women } \\
\hline \multicolumn{3}{|c|}{ If you absolutely needed $1,000 \mathrm{Ksh}$, where would you get the money? } \\
\hline Would use savings & 0.08 & 1221 \\
\hline Would work more & 0.12 & 1221 \\
\hline Spouse would work more & 0.09 & 1221 \\
\hline Would borrow from friend/relative/neighbor & 0.45 & 1221 \\
\hline Would get donations from friend/relative/neighbor & 0.16 & 1221 \\
\hline Would get a loan from ROSCA & 0.06 & 1221 \\
\hline Would sell household asset / animal / land & 0.12 & 1221 \\
\hline Would sell business asset & 0.01 & 1221 \\
\hline Would sell agricultural product & 0.15 & 1221 \\
\hline Other & 0.08 & 1221 \\
\hline \multicolumn{3}{|l|}{ Panel C. Men } \\
\hline \multicolumn{3}{|c|}{ If you absolutely needed $1,000 \mathrm{Ksh}$, where would you get the money? } \\
\hline Would use savings & 0.20 & 763 \\
\hline Would work more & 0.16 & 763 \\
\hline Spouse would work more & 0.04 & 763 \\
\hline Would borrow from friend/relative/neighbor & 0.38 & 763 \\
\hline Would get donations from friend/relative/neighbor & 0.08 & 763 \\
\hline Would get a loan from ROSCA & 0.05 & 763 \\
\hline Would sell household asset / animal / land & 0.14 & 763 \\
\hline Would sell business asset & 0.01 & 763 \\
\hline Would sell agricultural product & 0.13 & 763 \\
\hline Other & 0.09 & 763 \\
\hline
\end{tabular}

Data: Full census sample. Respondents could give more than one answer to the question (i.e. categories are not mutually exclusive). 


\section{Panel A. All}

Have you heard of the Village Bank?

Do you trust the Village Bank?

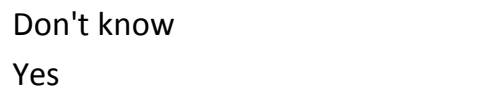

No

Of those who don't trust the Village Bank, why?

Worried that the Village Bank will take my money

Don't know the Village Bank / unfamiliar with banking

Fees are high

No interest

Bank is unreliable

Other

\section{Panel B. Women}

Have you heard of the Village Bank?

Do you trust the Village Bank?

Don't know

Yes

No

Of those who don't trust the Village Bank, why?

Worried that the Village Bank will take my money

Don't know the Village Bank / unfamiliar with banking

Fees are high

No interest

Bank is unreliable

Other

\section{Panel C. Men}

Have you heard of the Village Bank?

Do you trust the Village Bank?

Don't know

Yes

No

Of those who don't trust the Village Bank, why?

Worried that the Village Bank will take my money

Don't know the Village Bank / unfamiliar with banking

Fees are high

No interest

Bank is unreliable

Other

$\begin{array}{lllll}0.23 & 0.10 & 0.49 & 0.17 & 111 \\ 0.43 & 0.64 & 0.23 & 0.29 & 111 \\ 0.10 & 0.08 & 0.11 & 0.13 & 111 \\ 0.04 & 0.02 & 0.06 & 0.04 & 111 \\ 0.08 & 0.04 & 0.03 & 0.25 & 111 \\ 0.12 & 0.14 & 0.09 & 0.13 & 111\end{array}$

$\begin{array}{lllll}0.60 & 0.64 & 0.64 & 0.51 & 2018 \\ 0.43 & 0.41 & 0.44 & 0.46 & 1191 \\ 0.49 & 0.52 & 0.48 & 0.46 & 1191 \\ 0.08 & 0.08 & 0.08 & 0.09 & 1191\end{array}$

0.12

$\begin{array}{lllll}0.55 & 0.61 & 0.57 & 0.43 & 1492 \\ 0.44 & 0.41 & 0.46 & 0.49 & 803 \\ 0.49 & 0.53 & 0.46 & 0.44 & 803 \\ 0.07 & 0.07 & 0.08 & 0.07 & 803\end{array}$

$\begin{array}{lllll}0.25 & 0.11 & 0.56 & 0.25 & 67 \\ 0.46 & 0.57 & 0.28 & 0.42 & 67 \\ 0.09 & 0.08 & 0.11 & 0.08 & 67 \\ 0.02 & 0.03 & 0.00 & 0.00 & 67 \\ 0.05 & 0.03 & 0.00 & 0.17 & 67 \\ 0.13 & 0.19 & 0.06 & 0.08 & 67\end{array}$

Notes: Data is from the full census sample. The Village Bank in Market A had a freeze on withdrawals a few months prior to the survey. The bank in Market $C$ does not allow withdrawals and is often closed during business hours. 
Table 7. Familiarity with Local Financial Institutions among the Unbanked

\begin{tabular}{|c|c|c|c|c|c|}
\hline & All & Market A & Market B & Market C & \# obs \\
\hline \multicolumn{6}{|l|}{ Panel A. All } \\
\hline \multirow[t]{2}{*}{ Distance to closest deposit-taking branch (in km) } & 1.63 & 1.87 & 1.40 & 1.49 & 1260 \\
\hline & $(0.71)$ & (0.69) & (0.77) & (0.52) & \\
\hline \multirow[t]{2}{*}{ Distance to closest branch offering withdrawals (in km) } & 3.04 & 1.87 & 1.40 & 7.00 & 1260 \\
\hline & (2.44) & (0.69) & $(0.77)$ & (0.73) & \\
\hline Has heard of the local Village Bank & 0.52 & 0.54 & 0.57 & 0.45 & 1122 \\
\hline If yes: Knows account opening fee at local Village Bank & 0.08 & 0.11 & 0.07 & 0.00 & 389 \\
\hline Has heard of local Commercial Bank ${ }^{1}$ & & 0.59 & & & 125 \\
\hline If yes: Knows Comm. Bank accounts are free to open & & 0.00 & & & 71 \\
\hline Would use bank account if had one & 0.85 & 0.85 & 0.87 & 0.83 & 1468 \\
\hline Would choose Village Bank over Commercial bank if had choice & 0.38 & 0.31 & 0.47 & 0.41 & 1320 \\
\hline \multicolumn{6}{|l|}{ Panel B. Women } \\
\hline \multirow[t]{2}{*}{ Distance to closest deposit-taking branch (in km) } & 1.60 & 1.85 & 1.37 & 1.46 & 828 \\
\hline & (0.71) & (0.69) & (0.77) & (0.53) & \\
\hline \multirow[t]{2}{*}{ Distance to closest branch offering withdrawals (in km) } & 3.01 & 1.85 & 1.37 & 7.01 & 828 \\
\hline & $(2.45)$ & (0.69) & $(0.77)$ & $(0.73)$ & \\
\hline Has heard of the local Village Bank & 0.47 & 0.52 & 0.49 & 0.37 & 914 \\
\hline If yes: Knows account opening fee at local Village Bank & 0.05 & 0.09 & 0.03 & 0.00 & 247 \\
\hline Has heard of local Commercial Bank & & 0.54 & & & 71 \\
\hline If yes: Knows Comm. Bank accounts are free to open & & 0.00 & & & 37 \\
\hline Would use bank account if had one & 0.81 & 0.82 & 0.82 & 0.79 & 958 \\
\hline Would choose Village Bank over Commercial bank if had choice & 0.39 & 0.31 & 0.48 & 0.45 & 858 \\
\hline \multicolumn{6}{|l|}{ Panel C. Men } \\
\hline \multirow[t]{2}{*}{ Distance to closest deposit-taking branch (in km) } & 1.67 & 1.92 & 1.45 & 1.54 & 432 \\
\hline & $(0.72)$ & $(0.70)$ & (0.79) & $(0.50)$ & \\
\hline \multirow[t]{2}{*}{ Distance to closest branch offering withdrawals (in km) } & 3.08 & 1.92 & 1.45 & 6.99 & 432 \\
\hline & $(2.44)$ & $(0.70)$ & $(0.79)$ & $(0.73)$ & \\
\hline Has heard of the local Village Bank & 0.73 & 0.71 & 0.80 & 0.67 & 208 \\
\hline If yes: Knows account opening fee at local Village Bank & 0.14 & 0.14 & 0.15 & 0.00 & 142 \\
\hline Has heard of local Commercial Bank & & 0.67 & & & 54 \\
\hline If yes: Knows Comm. Bank accounts are free to open & & 0.00 & & & 34 \\
\hline Would use bank account if had one & 0.92 & 0.91 & 0.98 & 0.91 & 510 \\
\hline Would choose Village Bank over Commercial Bank if had choice & 0.36 & 0.31 & 0.45 & 0.34 & 462 \\
\hline
\end{tabular}

Notes: Data consists of restricted experimental sample. Standard deviations in parentheses.

${ }^{1}$ This question only asked in Market A (where the Commercial Bank has a branch). 
Table 8. Experimental Results: Take-up and Usage of Free Accounts among those Initially Unbanked

Opened an account

\begin{tabular}{|c|c|c|c|c|}
\hline All & Market A & Market B & Market C & \# obs \\
\hline 0.625 & 0.613 & 0.753 & 0.530 & 840 \\
\hline 0.427 & 0.175 & 0.744 & 0.526 & 840 \\
\hline 0.198 & 0.438 & 0.009 & 0.004 & 840 \\
\hline 0.28 & 0.36 & 0.27 & 0.17 & 525 \\
\hline \multirow[t]{2}{*}{0.23} & 0.22 & 0.28 & 0.17 & 359 \\
\hline & 0.39 & & & 166 \\
\hline 4.58 & 4.57 & 4.71 & 4.36 & 147 \\
\hline (3.48) & (3.46) & (3.44) & (3.79) & \\
\hline 4,314 & 6,477 & 2,221 & 730 & 147 \\
\hline$(10,231)$ & $(13,174)$ & $(3,836)$ & $(1,818)$ & \\
\hline 862 & 1,288 & 460 & 132 & 147 \\
\hline$(2,223)$ & $(2,901)$ & (713) & (228) & \\
\hline 1.68 & 2.27 & 1.42 & 0 & 148 \\
\hline (3.71) & (4.49) & (2.67) & & \\
\hline 1,455 & 1,760 & 845 & 0 & 66 \\
\hline (1990) & (2269) & (1063) & & \\
\hline 0.058 & 0.060 & 0.039 & 0.078 & 397 \\
\hline 0.176 & 0.218 & 0.206 & 0.089 & \\
\hline
\end{tabular}

Overall: Active Take-Up of Free Account

Data: Subset of individuals sampled for free account (among restricted experimental sample). Accounts were opened in May-July 2010 and follow-up data is from May 2011 (approximately 10-12 months after account opening). Standard deviations in parentheses.

Monetary values in Kenyan shillings (Ksh). Exchange rate was roughly $80 \mathrm{Ksh}$ to \$1 US during sample period.

${ }^{1}$ Accounts at the Commercial Bank were only offered in Market A (where the Commercial Bank has a branch). 
Table 9. Experimental Results: Take-up and Usage of Free Accounts among those Initially Unbanked (By Gender)

\begin{tabular}{|c|c|c|}
\hline & Women & Men \\
\hline Opened an account & 0.611 & 0.649 \\
\hline Opened account at Village Bank & 0.415 & 0.448 \\
\hline \multicolumn{2}{|l|}{ If opened an account: } & 0.201 \\
\hline "Active" ( = at least 2 deposits) & 0.32 & 0.22 \\
\hline If Village Bank account: "Active" & 0.27 & 0.16 \\
\hline If Commercial Bank account: "Active" ${ }^{1}$ & 0.41 & 0.34 \\
\hline \multirow[t]{2}{*}{ If "Active": Average number of deposits } & 4.29 & 5.27 \\
\hline & $(3.26)$ & $(3.91)$ \\
\hline \multirow[t]{2}{*}{ Total deposited on account (Ksh) } & 1,966 & 9,637 \\
\hline & (3955) & $(16421)$ \\
\hline \multirow[t]{2}{*}{ Average deposit size (Ksh) } & 480 & 1,727 \\
\hline & $(1144)$ & $(3506)$ \\
\hline \multirow[t]{2}{*}{ Average number of withdrawals } & 0.96 & 3.31 \\
\hline & (1.56) & (6.03) \\
\hline \multirow[t]{2}{*}{ Average withdrawal size (Ksh) } & 1,059 & 2,148 \\
\hline & (1658) & (2345) \\
\hline Account joint with spouse (if married) & 0.071 & 0.045 \\
\hline Overall: Active Take-Up of Free Account & 0.197 & 0.140 \\
\hline Observations & 532 & 308 \\
\hline \multicolumn{3}{|c|}{$\begin{array}{l}\text { Data: Subset of individuals sampled for free account (among restricted experimental sample). Accounts were opened in } \\
\text { May-July } 2010 \text { and follow-up data is from May } 2011 \text { (approximately 10-12 months after account opening). Standard } \\
\text { deviations in parentheses. Monetary values in Kenyan shillings (Ksh). Exchange rate was roughly } 80 \text { Ksh to \$1 US during } \\
\text { sample period. }\end{array}$} \\
\hline
\end{tabular}




\begin{tabular}{|c|c|c|c|}
\hline & Commercial Bank & Village Bank & Mobile Money \\
\hline \multicolumn{4}{|l|}{ Concerns with Savings Option: } \\
\hline Unreliable & 0.16 & 0.32 & 0.01 \\
\hline Distance & 0.11 & 0.02 & 0.02 \\
\hline Risk of embezzlement & 0.06 & 0.17 & 0.00 \\
\hline Requires phone & - & - & 0.36 \\
\hline Observations & 283 & 294 & 292 \\
\hline \multicolumn{4}{|c|}{ Panel B. Non-Compliers (Offered Account Voucher but did not open account or is not actively using account) } \\
\hline \multicolumn{4}{|c|}{ Concerns with Savings Option: } \\
\hline Agent can't always handle transactions & - & - & 0.33 \\
\hline Requires phone & - & - & 0.38 \\
\hline Observations & 285 & 284 & 284 \\
\hline \multicolumn{4}{|c|}{ Panel C. Compliers (Offered Account Voucher, opened account and actively using account) } \\
\hline \multicolumn{4}{|l|}{ Concerns with Savings Option: } \\
\hline Fees & 0.46 & 0.16 & 0.09 \\
\hline Unreliable & 0.17 & 0.43 & 0.01 \\
\hline Distance & 0.11 & 0.02 & 0.01 \\
\hline Risk of embezzlement & 0.06 & 0.21 & 0.00 \\
\hline
\end{tabular}

Data: Restricted experimental sample.

${ }^{1}$ If customers make a large number of withdrawals on a given day, the agent may run out of liquidity. If customers make a large number of deposits, he may run out of e-float. See text for more details. 
Panel A. Control Group (No Account Voucher)

Concerns with Village Bank

\begin{tabular}{|c|c|c|c|c|}
\hline Fees & 0.15 & 0.19 & 0.07 & 0.17 \\
\hline Unreliable & 0.32 & 0.33 & 0.21 & 0.40 \\
\hline Distance & 0.02 & 0.01 & 0.03 & 0.01 \\
\hline Risk of Embezzlement & 0.17 & 0.19 & 0.14 & 0.16 \\
\hline \multicolumn{5}{|l|}{ Preferred Banking Option } \\
\hline Commercial Bank & 0.43 & 0.40 & 0.40 & 0.49 \\
\hline Village Bank & 0.07 & 0.05 & 0.10 & 0.08 \\
\hline Mpesa & 0.06 & 0.08 & 0.07 & 0.02 \\
\hline Animals & 0.21 & 0.22 & 0.25 & 0.15 \\
\hline ROSCA & 0.11 & 0.11 & 0.06 & 0.15 \\
\hline Grain & 0.07 & 0.07 & 0.10 & 0.05 \\
\hline $\begin{array}{l}\text { Have you ever been discouraged } \\
\text { to open an account by a friend or relative? }\end{array}$ & 0.17 & 0.19 & 0.16 & 0.14 \\
\hline Observations & 294 & 138 & 73 & 83 \\
\hline
\end{tabular}

Panel B. Non-Compliers (Offered Account Voucher but did not open account or is not actively using account) Concerns with Village Bank

\begin{tabular}{|c|c|c|c|c|}
\hline Fees & 0.21 & 0.23 & 0.27 & 0.12 \\
\hline Unreliable & 0.37 & 0.34 & 0.36 & 0.40 \\
\hline Distance & 0.03 & 0.02 & 0.03 & 0.05 \\
\hline Risk of Embezzlement & 0.24 & 0.26 & 0.21 & 0.23 \\
\hline \multicolumn{5}{|l|}{ Preferred Banking Option } \\
\hline Commercial Bank & 0.36 & 0.39 & 0.30 & 0.35 \\
\hline Village Bank & 0.17 & 0.06 & 0.30 & 0.23 \\
\hline Mpesa & 0.04 & 0.05 & 0.04 & 0.02 \\
\hline Animals & 0.22 & 0.22 & 0.19 & 0.25 \\
\hline ROSCA & 0.07 & 0.10 & 0.03 & 0.07 \\
\hline Grain & 0.08 & 0.09 & 0.08 & 0.07 \\
\hline $\begin{array}{l}\text { Have you ever been discouraged } \\
\text { to open an account by a friend or relative? }\end{array}$ & 0.24 & 0.24 & 0.27 & 0.21 \\
\hline Dservations & 284 & 125 & 70 & 89 \\
\hline
\end{tabular}

Panel C. Compliers (Offered Account Voucher, opened account and actively using account) Concerns with Village Bank

\begin{tabular}{|c|c|c|c|c|}
\hline Fees & 0.16 & 0.11 & 0.32 & 0.12 \\
\hline Unreliable & 0.43 & 0.41 & 0.26 & 0.65 \\
\hline Distance & 0.02 & 0.00 & 0.11 & 0.00 \\
\hline Risk of Embezzlement & 0.21 & 0.28 & 0.11 & 0.12 \\
\hline \multicolumn{5}{|l|}{ Preferred Banking Option } \\
\hline Commercial Bank & 0.49 & 0.67 & 0.20 & 0.35 \\
\hline Village Bank & 0.29 & 0.13 & 0.55 & 0.41 \\
\hline Mpesa & 0.02 & 0.02 & 0.05 & 0.00 \\
\hline Animals & 0.12 & 0.09 & 0.10 & 0.24 \\
\hline ROSCA & 0.04 & 0.02 & 0.10 & 0.00 \\
\hline Grain & 0.04 & 0.07 & 0.00 & 0.00 \\
\hline $\begin{array}{l}\text { Have you ever been discouraged } \\
\text { to open an account by a friend or relative? }\end{array}$ & 0.31 & 0.26 & 0.40 & 0.31 \\
\hline Observations & 82 & 46 & 19 & 17 \\
\hline
\end{tabular}


Table 12. Baseline Knowledge of Local Credit Opportunities and Interest in Loans among those Initially Unbanked

\begin{tabular}{lll}
\hline \hline & & \\
& All & \# obs \\
\cline { 2 - 3 } Is there a local institution in which you can get loans? & & \\
Yes & 0.64 & 665 \\
No & 0.11 & 665 \\
Don't know & 0.26 & 665 \\
& & \\
Correctly identified Village Bank as local credit option & 0.38 & 667 \\
Correctly identified Commercial Bank as local credit option ${ }^{1}$ & 0.41 & 311 \\
Says knows procedure for loan & 0.15 & 660 \\
Really knows procedure for loan & 0.07 & 658 \\
& & \\
Interested in loan at 1.5\% monthly interest without collateral & 0.74 & 645 \\
Interested in loan at 1.5\% monthly interest with full collateral & 0.32 & 643 \\
& & \\
Do you think you could qualify for a loan? & & 664 \\
Yes & 0.37 & 664 \\
No & 0.22 & 664 \\
Don't know & 0.41 & \\
Has ever applied for loan & & 537 \\
Has ever gotten loan & 0.06 & 536 \\
\hline Data: Random subset of restricted expermental sample.
\end{tabular}

Data: Random subset of restricted experimental sample.

${ }^{1}$ This question was only asked in Market A, where the Commercial Bank has a branch. 
Table 13. Interest in Loans among those initially Unbanked, Immediately After Receiving Information on Local Credit Opportunities

\begin{tabular}{|c|c|c|}
\hline & All & \# obs \\
\hline Interested in loan at Village Bank & 0.60 & 645 \\
\hline Interested in loan at Commercial Bank & 0.35 & 644 \\
\hline \multicolumn{3}{|l|}{ If interested in a loan : Purpose of Loan ${ }^{1}$} \\
\hline Farm inputs & 0.11 & 98 \\
\hline Farm equipment & 0.02 & 98 \\
\hline Start business & 0.77 & 98 \\
\hline Business inventory & 0.19 & 98 \\
\hline Business equipment & 0.09 & 98 \\
\hline Home construction & 0.04 & 98 \\
\hline Home repair & 0.00 & 98 \\
\hline Furniture & 0.01 & 98 \\
\hline School fees & 0.08 & 98 \\
\hline Health care & 0.00 & 98 \\
\hline Wedding & 0.00 & 98 \\
\hline Land & 0.01 & 98 \\
\hline Debts & 0.00 & 98 \\
\hline Other & 0.11 & 98 \\
\hline \multicolumn{3}{|l|}{ If interested in a loan: Desired Loan Amount (in Ksh) } \\
\hline Mean & 18878 & 95 \\
\hline Median & 10000 & 95 \\
\hline Standard Deviation & 31813 & \\
\hline Months needed before can make first repayment & 2.15 & 95 \\
\hline$\%$ say would be able to make first payment within 1 month & 0.41 & 95 \\
\hline$\%$ say would be able to make first payment within 2 months & 0.70 & 95 \\
\hline
\end{tabular}

Data: Results restricted to those who received the credit intervention.

${ }^{1}$ Due to problem in the skip code on a version of the survey, this question was only asked for a subset of people who were interested in a loan. 
Table 14. Experimental Results: Impacts of Credit Intervention

\begin{tabular}{|c|c|c|}
\hline & All & \# obs \\
\hline \multicolumn{3}{|c|}{ Panel A. Share Voucher + Information Intervention } \\
\hline \multicolumn{3}{|l|}{ All } \\
\hline Accepted Voucher & 0.87 & 358 \\
\hline Redeemed Voucher & 0.40 & 358 \\
\hline Inquired about loan at Village Bank & 0.028 & 358 \\
\hline Completed loan training at Village Bank & 0.011 & 358 \\
\hline Formed group at Village Bank & 0.014 & 358 \\
\hline Got loan at Village Bank ${ }^{1}$ & 0.003 & 358 \\
\hline \multicolumn{3}{|l|}{ Women } \\
\hline Accepted Voucher & 0.85 & 233 \\
\hline Redeemed Voucher & 0.37 & 233 \\
\hline Inquired about loan at Village Bank & 0.043 & 233 \\
\hline Completed loan training at Village Bank & 0.017 & 233 \\
\hline Formed group at Village Bank & 0.021 & 233 \\
\hline Got loan at Village Bank & 0.004 & 233 \\
\hline \multicolumn{3}{|l|}{ Men } \\
\hline Accepted Voucher & 0.91 & 125 \\
\hline Redeemed Voucher & 0.46 & 125 \\
\hline Inquired about loan at Village Bank & 0.00 & 125 \\
\hline Completed loan training at Village Bank & 0.000 & 125 \\
\hline Formed group at Village Bank & 0.000 & 125 \\
\hline Got loan at Village Bank & 0.000 & 125 \\
\hline \multicolumn{3}{|l|}{ Panel B. Information Only Intervention } \\
\hline \multicolumn{3}{|l|}{ All } \\
\hline Inquired about loan at Village Bank & 0.00 & 296 \\
\hline Completed loan training at Village Bank & 0.00 & 296 \\
\hline Formed group at Village Bank & 0.00 & 296 \\
\hline Got loan at Village Bank & 0.00 & 296 \\
\hline \multicolumn{3}{|l|}{ Women } \\
\hline Inquired about loan at Village Bank & 0.00 & 196 \\
\hline Completed loan training at Village Bank & 0.00 & 196 \\
\hline Formed group at Village Bank & 0.00 & 196 \\
\hline Got loan at Village Bank & 0.00 & 196 \\
\hline \multicolumn{3}{|l|}{ Men } \\
\hline Inquired about loan at Village Bank & 0.00 & 100 \\
\hline Completed loan training at Village Bank & 0.00 & 100 \\
\hline Formed group at Village Bank & 0.00 & 100 \\
\hline Got loan at Village Bank & 0.00 & 100 \\
\hline
\end{tabular}

Data: See text for detailed description of interventions. Loan take-up is updated through 31 August 2011. Respondents in Panel A received both a voucher for 1 share at the bank and information on how to apply for a loan. Respondents in Panel B received information only. Information on loan take-up is from the Village Bank only. As of August 31, 2011, no respondents had applied for a loan at the Commercial Bank.

${ }^{1}$ Exactly one person had qualified for a loan by August 31, 2011. 
Table 15. What factors might prevent you from getting a loan?

\begin{tabular}{lll}
\hline \hline & & All \\
\cline { 2 - 3 } Don't need the money & 0.14 & 179 \\
Afraid bank will seize collateral & 0.51 & 179 \\
Too risky & 0.45 & 179 \\
Don't trust the bank & 0.09 & 179 \\
Don't like the idea of being in debt & 0.08 & 179 \\
Have too much other debt & 0.01 & 179 \\
Too much hassle & 0.12 & 179 \\
I don't have a business which is required for loan & 0.27 & 179 \\
I can't pay immediately & 0.18 & 179 \\
Other & 0.38 & 179 \\
\hline
\end{tabular}

Data: Results restricted to those who received the credit intervention. 


\begin{tabular}{|c|c|c|c|c|}
\hline & All & Female & Male & \# obs \\
\hline \multicolumn{5}{|l|}{ Panel A. Farmers } \\
\hline \multicolumn{5}{|l|}{ Informal Savings } \\
\hline Participates in ROSCA & 0.39 & 0.42 & 0.32 & 1576 \\
\hline \multirow[t]{2}{*}{ Number of ROSCAs (for those who participate) } & 1.43 & 1.46 & 1.35 & 620 \\
\hline & $(0.74)$ & $(0.77)$ & $(0.60)$ & \\
\hline \multirow[t]{2}{*}{ ROSCA contributions in past year (for those who participate) } & 4362 & 4205 & 4881 & 643 \\
\hline & $(7245)$ & $(6147)$ & $(10051)$ & \\
\hline \multicolumn{5}{|l|}{ Formal Savings } \\
\hline Has Account in Formal Deposit-Taking Institution & 0.08 & 0.06 & 0.15 & 1657 \\
\hline Has Account in Commercial Bank & 0.04 & 0.02 & 0.09 & 1657 \\
\hline Has Account in Post Bank & 0.01 & 0.01 & 0.02 & 1657 \\
\hline Has Account in Village Bank & 0.04 & 0.03 & 0.05 & 1657 \\
\hline Has Account with MFI & 0.00 & 0.00 & 0.00 & 1657 \\
\hline Has Account Elsewhere & 0.01 & 0.01 & 0.01 & 1657 \\
\hline Has Mobile Money Account & 0.13 & 0.09 & 0.24 & 1657 \\
\hline \multicolumn{5}{|l|}{ Panel B. Non-Farmers } \\
\hline \multicolumn{5}{|l|}{ Informal Savings } \\
\hline Participates in ROSCA & 0.45 & 0.53 & 0.39 & 1014 \\
\hline \multirow[t]{2}{*}{ Number of ROSCAs (for those who participate) } & 1.60 & 1.72 & 1.46 & 455 \\
\hline & $(0.87)$ & $(0.89)$ & $(0.82)$ & \\
\hline \multirow[t]{2}{*}{ ROSCA contributions in past year (for those who participate) } & 8731 & 7797 & 9704 & 443 \\
\hline & $(13451)$ & $(11302)$ & $(15340)$ & \\
\hline \multicolumn{5}{|l|}{ Formal Savings } \\
\hline Has Account in Formal Deposit-Taking Institution & 0.23 & 0.19 & 0.25 & 1197 \\
\hline Has Account in Commercial Bank & 0.15 & 0.09 & 0.18 & 1197 \\
\hline Has Account in Post Bank & 0.02 & 0.02 & 0.02 & 1197 \\
\hline Has Account in Village Bank & 0.07 & 0.10 & 0.06 & 1197 \\
\hline Has Account with MFI & 0.00 & 0.00 & 0.00 & 1197 \\
\hline Has Account Elsewhere & 0.03 & 0.02 & 0.04 & 1197 \\
\hline Has Mobile Money Account & 0.26 & 0.19 & 0.31 & 1197 \\
\hline
\end{tabular}

Data: Full census sample. 
Appendix Table A2. Baseline Knowledge of Local Credit Opportunities and Interest in Loans among those Initially Unbanked (Farmers vs. Non Farmers)

\begin{tabular}{|c|c|c|c|c|}
\hline & All & Female & Male & \# obs \\
\hline \multicolumn{5}{|l|}{ Panel A. Farmers } \\
\hline \multicolumn{5}{|l|}{ Is there a local institution in which you can get loans? } \\
\hline Yes & 0.59 & 0.55 & 0.73 & 451 \\
\hline No & 0.12 & 0.13 & 0.08 & 451 \\
\hline Don't know & 0.29 & 0.33 & 0.19 & 451 \\
\hline Correctly identified Village Bank as local credit option & 0.34 & 0.30 & 0.47 & 452 \\
\hline Correctly identified Commercial Bank as local credit option & 0.37 & 0.31 & 0.55 & 212 \\
\hline Says knows procedure for loan & 0.12 & 0.11 & 0.17 & 446 \\
\hline Really knows procedure for loan & 0.05 & 0.04 & 0.09 & 444 \\
\hline Has ever applied for loan & 0.05 & 0.04 & 0.08 & 360 \\
\hline Has ever gotten loan & 0.04 & 0.03 & 0.04 & 359 \\
\hline \multicolumn{5}{|l|}{ Do you think you could qualify for a loan? } \\
\hline Yes & 0.34 & 0.30 & 0.46 & 449 \\
\hline No & 0.21 & 0.24 & 0.14 & 449 \\
\hline Don't know & 0.45 & 0.46 & 0.40 & 449 \\
\hline Interested in loan at $1.5 \%$ monthly interest without collateral & 0.74 & 0.71 & 0.85 & 424 \\
\hline Interested in loan at $1.5 \%$ monthly interest with full collateral & 0.27 & 0.22 & 0.47 & 423 \\
\hline \multicolumn{5}{|l|}{ Panel B. Non-Farmers } \\
\hline \multicolumn{5}{|l|}{ Is there a local institution in which you can get loans? } \\
\hline Yes & 0.74 & 0.62 & 0.84 & 196 \\
\hline No & 0.09 & 0.11 & 0.07 & 196 \\
\hline Don't know & 0.17 & 0.28 & 0.09 & 196 \\
\hline Correctly identified Village Bank as local credit option & 0.47 & 0.34 & 0.58 & 197 \\
\hline Correctly identified Commercial Bank as local credit option & 0.47 & 0.38 & 0.56 & 95 \\
\hline Says knows procedure for loan & 0.19 & 0.12 & 0.24 & 196 \\
\hline Really knows procedure for loan & 0.09 & 0.06 & 0.11 & 196 \\
\hline Has ever applied for loan & 0.09 & 0.06 & 0.11 & 160 \\
\hline Has ever gotten loan & 0.06 & 0.03 & 0.08 & 160 \\
\hline \multicolumn{5}{|l|}{ Do you think you could qualify for a loan? } \\
\hline Yes & 0.43 & 0.30 & 0.52 & 197 \\
\hline No & 0.24 & 0.30 & 0.19 & 197 \\
\hline Don't know & 0.34 & 0.40 & 0.29 & 197 \\
\hline Interested in loan at $1.5 \%$ monthly interest without collateral & 0.73 & 0.67 & 0.77 & 204 \\
\hline Interested in loan at $1.5 \%$ monthly interest with full collateral & 0.41 & 0.29 & 0.50 & 203 \\
\hline
\end{tabular}

Data: Random subset of restricted experimental sample.

${ }^{1}$ This question was only asked in Market A, where the Commercial Bank has a branch. 